\title{
Comparative Study of the Pharmacological Properties and Biological Effects of Polygonum aviculare L. herba Extract-Entrapped Liposomes versus Quercetin-Entrapped Liposomes on Doxorubicin-Induced Toxicity on HUVECs
}

\author{
Mariana Mureşan ${ }^{1,+}$, Diana Olteanu ${ }^{2,+} \mathbb{D}$, Gabriela Adriana Filip ${ }^{2, * \mathbb{D}}$, Simona Clichici ${ }^{2}$, Ioana Baldea $2 \mathbb{D}$, \\ Tunde Jurca $^{3}$, Annamaria Pallag ${ }^{3}{ }^{D}$, Eleonora Marian ${ }^{3}$, Adina Frum ${ }^{4}$, Felicia Gabriela Gligor ${ }^{4}\left(\mathbb{D}\right.$, Paula Svera ${ }^{5}$, \\ Bogdan Stancu ${ }^{6}\left(\right.$ D) and Laura Vicaș ${ }^{3}(D)$
}

\section{check for} updates

Citation: Mureşan, M.; Olteanu, D.; Filip, G.A.; Clichici, S.; Baldea, I.; Jurca, T.; Pallag, A.; Marian, E.; Frum, A.; Gligor, F.G.; et al. Comparative Study of the Pharmacological Properties and Biological Effects of Polygonum aviculare L. herba Extract-Entrapped Liposomes versus

Quercetin-Entrapped Liposomes on Doxorubicin-Induced Toxicity on HUVECs. Pharmaceutics 2021, 13, 1418. https://doi.org/10.3390/ pharmaceutics13091418

Academic Editors: Lenuţa Maria Şuta and Claudia Geanina Watz

Received: 2 August 2021

Accepted: 3 September 2021

Published: 7 September 2021

Publisher's Note: MDPI stays neutral with regard to jurisdictional claims in published maps and institutional affiliations.

Copyright: (c) 2021 by the authors. Licensee MDPI, Basel, Switzerland. This article is an open access article distributed under the terms and conditions of the Creative Commons Attribution (CC BY) license (https:/ / creativecommons.org/licenses/by/ $4.0 /)$.
1 Department of Preclinical Disciplines, Faculty of Medicine and Pharmacy, University of Oradea, 10 Piata 1 Decembrie Street, 410073 Oradea, Romania; marianamur2002@yahoo.com

2 Department of Physiology, "Iuliu Hatieganu" University of Medicine and Pharmacy, 1-3 Clinicilor Street, 400006 Cluj-Napoca, Romania; ariana_di@yahoo.com (D.O.); simonaclichici@yahoo.com (S.C.);

baldeaioana@gmail.com (I.B.)

3 Department of Pharmacy, Faculty of Medicine and Pharmacy, University of Oradea, 29 Nicolae Jiga Street, 410028 Oradea, Romania; jurcatunde@yahoo.com (T.J.); annamariapallag@gmail.com (A.P.); marian_eleonora@yahoo.com (E.M.); laura.vicas@gmail.com (L.V.)

4 Faculty of Medicine, Lucian Blaga University Sibiu, Lucian Blaga Street, No. 2A, 550169 Sibiu, Romania; adinafrum@gmail.com (A.F.); feligligor@yahoo.fr (F.G.G.)

5 INCEMC-National Institute for Research and Development in Electrochemistry and Condensed Matter-Timisoara, No. 144 Dr. A. Paunescu Podeanu Street, 300569 Timisoara, Romania; paulasvera@gmail.com

6 2nd Department of General Surgery, Iuliu Hatieganu University of Medicine and Pharmacy, 400006 Cluj-Napoca, Romania; bstancu7@yahoo.com

* Correspondence: adrianafilip33@yahoo.com or gabriela.filip@umfcluj.ro

+ These authors contributed equally to this work.

\begin{abstract}
This study aimed to evaluate the comparative biological effects of Polygonum aviculare L. herba (PAH) extract and quercetin-entrapped liposomes on doxorubicin (Doxo)-induced toxicity in HUVECs. HUVECs were treated with two formulations of liposomes loaded with PAH extract (L5 and L6) and two formulations of liposomes loaded with quercetin (L3 prepared with phosphatidylcholine and L4 prepared with phosphatidylserine). The results obtained with atomic force microscopy, zeta potential and entrapment liposome efficiency confirmed the interactions of the liposomes with $\mathrm{PAH}$ or free quercetin and a controlled release of flavonoids entrapped in all the liposomes. Doxo decreased the cell viability and induced oxidative stress, inflammation, DNA lesions and apoptosis in parallel with the activation of Nrf2 and NF-kB. Free quercetin, L3 and L4 inhibited the oxidative stress and inflammation and reduced apoptosis, particularly L3. Additionally, these compounds diminished the Nrf2 and NF-kB expressions and DNA lesions, principally L4. PAH extract, L5 and L6 exerted antioxidant and anti-inflammatory activities, reduced $\gamma \mathrm{H} 2 \mathrm{AX}$ formation and inhibited extrinsic apoptosis and transcription factors activation but to a lesser extent. The loading of quercetin in liposomes increased the cell viability and exerted better endothelial protection compared to free quercetin, especially L3. The liposomes with PAH extract had moderate efficiency, mainly due to the antioxidant and anti-inflammatory effects and the inhibition of extrinsic apoptosis.
\end{abstract}

Keywords: liposomes; quercetin; Polygonum aviculare L. extract; doxorubicin; endothelial cells; cell death

\section{Introduction}

The cellular mimetic function of liposomes has attracted the attention of researchers in the medical and pharmaceutical fields due to their ability to be personalised and their 
properties to counteract the major disadvantages of bioactive molecules with regards to decreased stability, limited membrane permeability, short half-life and low bioavailability. Liposomes are closed vesicular structures composed of one or more phospholipid layers, which are formed when membrane lipids such as phosphatidylcholine (PC) and cholesterol $(\mathrm{CHO})$ are dispersed in an excess of water. Liposomes have the ability to be selectively absorbed by tissues rich in the reticuloendothelial system, including the liver, spleen and small bones. This property underpins the mechanism of vectorisation of the bioactive substance and its transport in the systemic circulation. The optimisation of drugs through changes in their bioactive compounds by way of entrapment in liposomal particulate systems brings benefits to pharmacotherapy by capitalising on their pharmacological potential. Therefore, the aims of the study are to show improvements in intracellular penetration and cell availability and an increase in specificity of action for bioactive substances entrapped in liposomes with the lowest possible size distribution. The method proposed is an ultrasound-assisted thin-film hydration method. Numerous compounds, such as polyphenols or anthocyanins, are secondary metabolites generated by plants as a defence mechanism against infections or rough pedoclimatic conditions. These phytochemicals are bioactive agents with proven antioxidant and anti-inflammatory properties and proapoptotic, antimicrobial and antifungal effects, which can reduce the toxicity of free radicals in the human body and preserve human health [1-3].

The polyphenols' role in the modulation of the metabolic, functional and toxicity features in the human body are limited by low oral bioavailability-specifically, absorption and metabolism - in relationship with the chemical structure, molecular size, degree of polymerisation and water solubility [4]. These limits are exceeded by the incorporation of polyphenols into different drug delivery systems, including cyclodextrin [5], simple emulsions, gels, solid lipid nanoparticles, lipid nanocapsules, nanoemulsion [6] or liposomes $[7,8]$.

The vegetal product used in this study originates from the Polygonum aviculare L. species, also known as common knotgrass. The Polygonum aviculare L. species is part of the Polygonaceae family [9-13], and their active compounds are identified especially in the aerial part of the plant. Polygonum aviculare L. herba $(\mathrm{PAH})$ was harvested during the blooming season in June. Numerous studies have demonstrated the anti-inflammatory [14,15], antimicrobial and antifungal effects of the plant $[14,16]$ due to flavonoids, quinones, anthraquinones phenylpropanoids and terpenoids from its composition. Their antioxidant and protective effects may be useful properties in counteracting the toxic action on normal cells of different drugs, including antibiotic and chemotherapeutic agents.

Doxorubicin (Doxo) is a commonly anthracycline chemotherapeutic drug used for a long time in the treatment schemes of malignant tumours, such as bladder, colon and breast, or in Kaposi's sarcoma, lymphoma and leukaemia [17,18]. Although it is very effective, it has a major disadvantage due to cardiotoxicity and endothelial vascular toxicity [19], which often result in heart failure and increase the noncancerous mortality [20]. The mechanisms of toxicity are owed to intracellular and mitochondrial redox imbalance [21] and intrinsic apoptotic induction by the activation of caspase- 3 and p53, as well as extrinsic pathway initiation via the Fas receptor and ligand stimulation. Doxo also inhibits the nuclear factor related to erythroid factor 2 (Nrf2), a transcription factor that controls the antioxidant genes and cytoprotective enzymes expressed in the cardiovascular system [22-24], reduces nitric oxide synthesis and upregulates nuclear factor (NF)-kB [25]. Therefore, the therapeutic strategy that associates Doxo with a natural antioxidant may be a good option to diminish the cardio and vascular endothelial toxicities [26,27].

Given these data, this study aims to optimise the preparation of bioactive substances entrapped in liposomes with the lowest possible size distribution and highest penetrability for biomedical applications. After the characterisation of liposomes loaded with quercetin and the PAH extract, their efficacy in the inhibition of Doxo-induced toxicity was tested comparative only with quercetin and the PAH extract on human endothelial cells (HUVECs). The mechanisms involved in the endotheliotoxicity of Doxo was evaluated by 
oxidative stress and inflammation markers, as well as caspases-3, -8 and -9; DNA lesions and transcription factor expressions. Quercetin was chosen for comparison, because it is an important component of the tested extract, and because it has demonstrated endothelialprotective properties on doxorubicin-induced toxicity [28]. Thus, on isolated aortic rings incubated with Doxo, quercetin restored the normal vascular contraction and relaxation impaired by Doxo exposure and diminished the ROS generation. In addition, quercetin inhibited the ERK/MAP-kinase activation and, thus, diminished the ROS-induced cardiomyopathy [29].

\section{Materials and Methods}

\subsection{Reagents}

The liposomes loaded with polyphenols from the Polygonum aviculare L. herb extract were prepared by the hydration method by using phosphatidylcholine, phosphatidylserine and cholesterol purchased from Sigma-Aldrich (Milan, Italy). The Polygonum aviculare L. herb was harvested from the Crișana region, Bihor County. A specimen from this species was kept in the herbarium of the Faculty of Medicine and Pharmacy Oradea, registered in the NYBG Steere Herbarium, code UOP 05168. Ethanol, n-butanol and phosphate buffer were obtained from Farmachim 10 SRL Ploiesti (Bucharest, Romania), while methanol pro-analysis (Promochem), chloroform pro-analysis, Folin-Ciocâlteu'phenol reagent and 2-thiobarbituric acid EDTANa2 were purchased from Merck KGaA (Darmstadt, Germany). Trolox was sourced from Chemical Industry Co Ltd. (Tokyo, Japan) and 2,2-diphenyl-1picrylhydrazyl; 2,2'-azino bis (3-ethylbenzothiazoline-6-sulfonicacid) diammonium salt; neocuproine and the following standards: 7-methoxicumarin, gallic acid, chlorogenic acid, caffeic acid, ferrulic acid, rosmarinic acid, ellagic acid, trans-p-coumaric acid, bergapten, delphinidin 3-rutinchlorid, diosmin, hyperoside, isopimpinellin, luteolin-7-glucoside, myricetin, quercetin, rutin and t-resveratrol were from Sigma Aldrich. Antibodies against NF-kB p65 (Ser536) (93H1), phospho (p)NF-kB, Nrf2 and glyceraldehyde 3-phosphate dehydrogenase (GAPDH) and the secondary peroxidase-linked antibodies were from Santa Cruz Biotechnology (Delaware Ave, Santa Cruz, CA, USA), while phosphorylated histone H2AX (pS139) ( $\gamma \mathrm{H} 2 \mathrm{AX}$ ) was from Stressgen Bioreagents Corporation (Victoria, BC, Canada). ELISA tests for IL- 6 and caspases-3, -8 and -9 were purchased from Elabscience (Houston, TX, USA), and the Bradford total protein concentration assay was from Bio-Rad (Hercules, CA, USA). The compounds used were of adequate purity, attested by analysis bulletins issued by the manufacturer.

\subsection{Obtaining the Lyophilised Extract of Polygonum aviculare L. herba}

In order to obtain the fluid extract, the maceration extraction method at a temperature of $20^{\circ} \mathrm{C}$ was used. PAH was dried pre-procedure in a dry room, sheltered from sunlight and with an average temperature of $22{ }^{\circ} \mathrm{C}$. The vegetal product was fragmented and sieved through a no. III pharmaceutical sieve [30,31]. The solvent used for extraction was a mix of ethyl-alcohol and distilled water $30 \%(v / v)$. The mass ratio of the vegetal product to the solvent was 1:10 $(\mathrm{m} / \mathrm{m})$. The ethyl-alcohol was removed by evaporation on a rotavapour model, Hei-VAP Precision-Platinum 3, at a temperature of $40^{\circ} \mathrm{C}, 80 \mathrm{rpm}$ and $200 \mathrm{mBars}$. The aqueous fraction left behind was frozen at a temperature of $-80^{\circ} \mathrm{C}$ and dried using the ALPHA 2-4 LSC plus laboratory lyophiliser.

\subsection{The Phytochemical Investigation of the Lyophilised PAH Extract}

- The physicochemical characterisation by the HPLC-PDA method

The identification and quantification of the bioactive phenolic compounds from the PAH extract was performed by using a Shimadzu Nexera-i LC-2040C 3D plus liquid chromatograph system equipped with a photodiode array detector (PDA). A Phenomenex $\mathrm{C} 18$ (2) $100 \mathrm{~A}, 150 \mathrm{~mm} \times 4.6 \mathrm{~mm} \times 5 \mu \mathrm{m}$ column was used, and it was kept at $30{ }^{\circ} \mathrm{C}$. The mobile phases used for elution consisted of methanol (A) and formic acid $0.1 \%(B)$. The gradient program used was: $5 \% \mathrm{~A}$ and $95 \% \mathrm{~B}$ from 0 to $3 \mathrm{~min}, 25 \% \mathrm{~A}$ and $75 \% \mathrm{~B}$ from 3 
to $6 \mathrm{~min}, 37 \% \mathrm{~A}$ and $63 \% \mathrm{~B}$ from 9 to $13 \mathrm{~min}, 54 \% \mathrm{~A}$ and $46 \% \mathrm{~B}$ from 18 to $22 \mathrm{~min}, 95 \% \mathrm{~A}$ and 5\% B from 26 to $29 \mathrm{~min}$ and 5\% A and 95\% B from 30 to $36 \mathrm{~min}$. The flow rate was $0.5 \mathrm{~mL} / \mathrm{min}$, and the injection volume was $10 \mu \mathrm{L}$. The detection was performed at multiple wavelengths: 254, 270, 275, 326, 337 and $360 \mathrm{~nm}$. The polyphenols from the extract were identified by comparing the retention times from the extract chromatograms with the ones from the standard solution chromatograms.

- The contents of the bioactive compounds

The contents of the bioactive compounds of the PAH extract (respectively, the total polyphenol and total flavonoid contents) were assessed. In order to evaluate the total polyphenol content, the Folin-Ciocâlteu method was used [32,33]. This method is based on the electron transfer reaction, measuring the reductive capacity of an antioxidant. The results of the Folin-Ciocâlteu method were very well-correlated with the results obtained from other antioxidant analyses, such as ABTS and DPPH. The total polyphenol content was calculated as the gallic acid equivalent (GAE/100 g) of dried plant based on the calibration line of gallic acid (5-500 $\left.\mathrm{mg} / \mathrm{L}, \mathrm{Y}=0.0027 \mathrm{x}-0.0055, R^{2}=0.9999\right)$. All determinations were performed in triplicate.

For the evaluation of the total flavonoid content, the aluminium chloride colorimetric method was used [34-37]. Quercetin was used for the standard calibration curve. The stock quercetin solution was prepared by dissolving 5-mg quercetin in 1-mL methanol, followed by a standard quercetin solution preparation with serial dilutions using methanol (5-200 $\mu \mathrm{g} / \mathrm{mL}$ ). The absorbance was read at a wavelength of $420 \mathrm{~nm}$ with an UV-Vis Varia spectrophotometer. The total flavonoid concentration was calculated based on the calibration line $\left(Y=0.0162 x+0.0044, R^{2}=0.999\right)$ and expressed as the quercetin equivalent (QE) $\mathrm{mg} / 100 \mathrm{~g}$ in dried plant. All determinations were performed in triplicate.

\subsection{Evaluation of Antioxidant Activity}

The antioxidant activity of the PAH extract using the methods: 2,2-diphenyl-1-picrylhydrazyl (DPPH), ABTS (2,29-azinobis-(3-ethylbenzothiazoline-6-sulfonic acid-ABTS•1), CUPRAC (CupricReducing Antioxidant Capacity) and FRAP (Ferric Reducing Antioxidant Power) [38].

\subsection{Preparation of Liposomes}

Six liposome formulations were prepared in the following way: 2 formulations of un-loaded liposomes (L1 and L2), 2 formulations of liposomes loaded with quercetin (L3 and L4) and 2 formulations of liposomes loaded with PAH extract (Table 1). The following lipids to prepare the liposomes were used: phosphatidylcholine (PC), phosphatidylserine (PS) and sodium cholate (CoN). The method chosen for preparation was the thin-film method [39]. In order to obtain comparable results between the liposomes loaded with active substances, the liposomes were loaded with 10-mg quercetin (L3 and L4), as well as 100-mg PAH extract (0.676- $\mu \mathrm{g}$ QE). As a first step, $5 \mathrm{~mL}$ of organic solvent was dissolved and mixed in chloroform, thus assuring adequate homogeneity and resulting in a clear lipid solution. In the second step, quercetin and PAH extract were included for entrapment in the lipid solution. After the compounds dissolved in chloroform, the solvent was removed, resulting in the formation of a lipid film in each receptacle. The organic solvent was removed by evaporation at a temperature of $40^{\circ} \mathrm{C}$ in a rotavapour model, Hei-VAP Precision-Platinum $3.80 \mathrm{rpm}$ and $200 \mathrm{mBars}$. The hydration of the dry lipid film was achieved by adding $2 \mathrm{~mL}$ of phosphate buffer solution with a $\mathrm{pH}=7.4$, followed by centrifugal shaking/stirring in a Hettich Model Universal-320R centrifuge at 10,000 rpm for $30 \mathrm{~min}$ and, finally, ultrasonication for another $30 \mathrm{~min}$ at room temperature. This process resulted in nanometric structures after ultrasonication. 
Table 1. The composition of the liposome formulations.

\begin{tabular}{|c|c|c|c|c|c|c|}
\hline Liposome Composition (mg) & L1 & L2 & L3 & L4 & L5 & L6 \\
\hline $\begin{array}{l}\text { Phosphatidylcholine } \\
\text { (PC) (mg) }\end{array}$ & 80 & - & 80 & - & 80 & - \\
\hline $\begin{array}{l}\text { Phosphatidylserine } \\
\text { (PS) (mg) }\end{array}$ & - & 80 & - & 80 & - & 80 \\
\hline Sodium cholate $(\mathrm{CoN})(\mathrm{mg})$ & 20 & 20 & 20 & 20 & 20 & 20 \\
\hline Cholesterolum (CHO) (mg) & 2.5 & 2.5 & 2.5 & 2.5 & 2.5 & 2.5 \\
\hline Quercetin (QE) (mg) & - & - & 10 & 10 & - & - \\
\hline $\begin{array}{l}\text { Polygonum aviculare herba extract } \\
\text { (PAH) (mg) }\end{array}$ & - & - & - & - & 100 & 100 \\
\hline
\end{tabular}

\subsection{Characterisation of Liposomes}

Dynamic light scattering (DLS) and zeta potential (ZP) measurements were done using a Zetasizer Nano ZS (Malvern Instruments, Worcestershire, UK). Polystyrene cells with $1-\mathrm{cm}$ optical path were used for size measurements. This technique was used to determine the particle size distribution profile, the shape of the particles being approximated as spherical. The advantage of this method is that it covers a wide range of dimensions (10-3-10-9 m). This method does not directly measure the particle size, it is calculated based on their effect on light diffusion, the results being conclusive in the case of spherical particles. For this reason, some uncertainties may arise about the sizes of the particles if they deviate from a spherical shape [40]. Atomic Force Microscopy (AFM) images were obtained using a Scanning Probe Microscopy Platform (MultiView-2000 system, Nanonics Imaging Ltd., Jerusalem, Israel) in normal conditions $\left(24-25^{\circ} \mathrm{C}\right)$. During the analysis, it was used tip-dopped with chromium, with a $20-\mathrm{nm}$ radius and $30-40-\mathrm{KHz}$ resonance. Before the analysis, all samples (L1-L6) were exposed to ultrasonication for one hour, followed by drop-casting on an AFM glass support (purchased from Nanonics Imaging Ltd., Jerusalem, Israel). The samples were dropped on the support twice, followed by a drying process at room temperature.

\subsection{Liposome Entrapment Efficiency}

In order to know the degree of liposomal quercetin entrapment, as well as the total flavonoids from the PAH extract, the liposomes were centrifuged at 10,000 rpm for $30 \mathrm{~min}$ to separate the substances. Following this, $0.5 \mathrm{~mL}$ of Triton X-100 $(0.5 \% \mathrm{v} / \mathrm{v})$ was added to each specimen to decompose the lipid membranes. Each specimen was diluted with methanol and then filtered. To evaluate the quantity of entrapped PAH extract, we determined the total flavonoid content using the colorimetric method described in this article in Section 3.2, using the same calibration curve. Blank probes were used as witness probes. The entrapment efficiency $(E E \%)$ was calculated with the equation below:

$$
E E(\%)=M / M_{t} \times 100
$$

where $M$ is the quantity of flavonoids loaded into the liposomes, and $M_{t}$ is the quantity of flavonoids from the extract [37]. The entrapment efficiency ( $E E \%)$ of the lipid vesicles loaded with quercetin and the PAH extract, respectively, as well as their stability over time, were performed at three different storage intervals—namely, at 10,30 and 60 days.

\subsection{In Vitro Studies on the Release of Flavonoids Entrapped in Liposomes Using a Franz Cell System}

The in vitro diffusion experiments were conducted according to the FDA SUPAC-SS recommendations, using a diffusion system with 6 Franz diffusion cells (Microette-Hanson System, model 57-6AS9, Copley Scientific Ltd., Nottingham, UK), with a diffusion surface of $1.767 \mathrm{~cm}^{2}$ and a volume of $6.5 \mathrm{~mL}$ for the receptor chamber. The receptor chamber in 
each diffusion cell was filled with saline phosphate buffer ( $\mathrm{pH} 7.4$ ) mixed with $30 \%$ freshly prepared ethanol, which was warmed and deaerated [41].

The synthetic membranes were hydrated by immersion in the receptor medium for $30 \mathrm{~min}$ before use and then placed between the donor and acceptor compartments of the Franz diffusion cell. Approximately $0.300 \mathrm{~g}$ of the specimen were weighed in the dosing capsule of each diffusion cell, followed by application onto the superior part of the Franz diffusion cell membrane surface. The diffusion cells were well-sealed by fixing the dosing capsule with a clamp, preventing the evaporation of the vehicle and assuring the integrity of the formulation for the entire duration of the study. During the test, the system was maintained at $32 \pm 1{ }^{\circ} \mathrm{C}$, and the receptor medium was continually stirred (600 rpm) with the help of a magnetic stirrer to avoid the effects of the diffusion layer. The diffusion membranes are made of polysulfone with a diameter of $25 \mathrm{~mm}$ and a pore size of $0.45 \mu \mathrm{m}$ (Tuffryn ${ }^{\circledR}$, PALL Life Sciences HT-450, batch T72556). Before starting the study, the diffusion membranes were wetted by immersion in the receptor medium and kept in contact for $15 \mathrm{~min}$. Next, $0.5 \mathrm{~mL}$ of the receptor solution were automatically withdrawn at $30 \mathrm{~min}$ and $45 \mathrm{~min}$ and $1,3,4,5,6,8,12$ and $24 \mathrm{~h}$ and were replaced with a fresh receptor medium to maintain a constant volume of $6.5 \mathrm{~mL}$ during the test.

The specimens underwent a UV spectrophotometric analysis with a PG INSTRUMENTS model UV-VIS T 92+ spectrophotometer at $510 \mathrm{~nm}$, which corresponded to the maximum absorption of quercetin in saline phosphate buffer $(\mathrm{pH}=7.4)$ with $30 \%$ ethanol. The results were evaluated by using the calibration curve for quercetin. Each formulation was tested in triplicate and the data presented as the mean $\pm \mathrm{SD}$ (standard deviation). The cumulative release rate or cumulative drug release $(\mathrm{CDR})$ was calculated using the equation:

$$
\operatorname{CDR}(\%)=Q_{n} / Q_{t} \times 100
$$

where $Q_{n}$ is the quercetin content and total flavonoid content at time $n$, and $Q_{t}$ is the initial entrapped substance content in the lipid vesicles [39].

\subsection{In Vitro Studies}

- Cell cultures

Commercial human umbilical vein endothelial cells (HUVEC) obtained from the European Collection of Cell Cultures (ECACC, Porton Down, Salisbury, UK) were used to test the toxicity of Doxo and the effects of free quercetin, PAH extract and liposomes prepared with quercetin or the PAH extract. The cells were multiplied in RPMI medium, supplemented with $10 \%$ foetal calf serum (FCS), antibiotics and anti-mycotics (Biochrom AG, Berlin, Germany) in a humidified $\mathrm{CO}_{2}$ incubator at $37^{\circ} \mathrm{C}$. The surfaces markers of the cells, ICAM-1, CD29, CD34, CD73, CD90 and CD105, were analysed using flow cytometry, as previously published [42]. Cell cultures in the 23rd to 26th passages were used. All reagents were purchased from Sigma Aldrich, Co (Heidelberg, Germany).

- Viability assay and cell lysates

The cells' survival under exposure to free quercetin; PAH extract and liposomes loaded with quercetin or PAH extract (L3, L4, L5 and L6) were tested through the colourimetric measurement of formazan using the CellTiter $96^{\circledR}$ AQueous Non-Radioactive Cell Proliferation Assay (Promega Corporation, Madison, WI, USA). HUVECs were cultivated at a density of $10^{4}$ /well in 96-well plaques (TPP, Trasadingen, Switzerland) for $24 \mathrm{~h}$ and then treated for $24 \mathrm{~h}$ with different doses of free quercetin (ranged between 0.001 and $100 \mu \mathrm{g} / \mathrm{mL}$ ), PAH extract (ranged between 0.006 and $0.678 \mu \mathrm{g} / \mathrm{mL}$ ), L3 and L4 (ranged between 0.001 and $100 \mu \mathrm{g} / \mathrm{mL}$ ) and L5 and L6 (ranged between 0.006 and $0.678 \mu \mathrm{g} / \mathrm{mL}$ ) formulations. For MTS, the optical density values were read at an absorbance of $540 \mathrm{~nm}$ using an ELISA plate reader (Tecan, Männedorf, Switzerland). Data are presented as a mean of OD540 \pm SD. All the experiments were conducted in triplicate. Untreated cultures exposed to medium were used as controls. 
For obtaining cell lysates, HUVECs cells seeded on Petri dishes at a density of $10^{4} / \mathrm{cm}^{2}$ were exposed for $24 \mathrm{~h}$ to quercetin; PAH extract and the L3, L4, L5 and L6 formulations at a dose of $0.01 \mu \mathrm{g} / \mathrm{mL}$ concomitant with $2-\mu \mathrm{g}$ Doxo $/ \mathrm{mL}$. Untreated cells were used as controls. After $24 \mathrm{~h}$, the cells were collected, and the cell lysates were obtained using the standard procedure [43]. Protein concentrations in the samples were evaluated by the Bradford method, according to the manufacturer's specifications (Bio-Rad, Hercules, CA, USA). All the experiments were performed in triplicate.

- Oxidative stress, apoptosis and inflammation markers assessment

For the evaluation of oxidative stress, malondialdehyde (MDA) was assessed using the fluorimetric method with 2-thiobarbituric acid [44]. The results were expressed as nmoles/mg protein. In order to evaluate the apoptosis, the caspases-3, -8 and -9 levels in the supernates were quantified by ELISA kits according to the manufacturer's instructions. As a marker of inflammation, the IL- 6 content in the supernates was also determined. The results were expressed as $\mathrm{ng} / \mathrm{mL}$.

- DNA lesions and transcription factors expressions

The expression of transcription factors NF-kB and its phosphorylated form (pNF-kB), as well as Nrf2, were evaluated by Western blotting, as previously described [45]. For the quantification of DNA lesions, the expression of $\gamma \mathrm{H} 2 \mathrm{AX}$ was also evaluated by Western blotting. Lysates (20-mg protein/lane) were separated by electrophoresis on SDS PAGE gels and then transferred to polyvinylidenedifluoride membranes. Blots were blocked and then incubated with antibodies against NF-kB 65 (Ser536) (93H1), phosphorylated NF-kB (pNF-kB), Nrf2, $\gamma \mathrm{H} 2 \mathrm{AX}$ and GAPDH. Then, the blots were washed and incubated with the corresponding secondary peroxidase-linked antibodies. GAPDH was used as the protein loading control. Proteins were detected using the Supersignal West Femto Chemiluminiscent substrate (Thermo Fisher Scientific, Bath, UK) and a Gel Doc Imaging system equipped with an XRS camera and Quantity One analysis software (Bio-Rad, Hercules, CA, USA).

\subsection{Statistical Analyses}

The statistical analysis was conducted by using one-way ANOVA followed by Dunnett's multiple range test. All reported data were expressed as the mean of triplicate measurements $\pm \mathrm{SD}$, and a $p$-value less than 0.05 was considered statistically significant.

\section{Results and Discussion}

\subsection{The Physicochemical Characterisation of PAH Extract by the HPLC-PDA Method}

The identification and quantification of bioactive phenolic compounds from the $\mathrm{PAH}$ extract was performed by using a Shimadzu Nexera-i LC-2040C 3D plus liquid chromatograph system equipped with a photodiode array detector (PDA). The polyphenols from the PAH extract were identified by comparing the retention times from the extract chromatograms with the ones from the standard solution chromatograms. The results obtained for the determination of the PAH extract content are presented in Table 2.

The most important compounds identified were phenolic acids, and the highest amounts of phytochemicals found in the PAH extract were: rosmarinic acid ( $2.65 \pm 16.089 \mathrm{mg} / 100-\mathrm{mg} \mathrm{DW})$, followed by delphinidin 3-rutinoside chloride (1.034 \pm $6.326 \mathrm{mg} / 100-\mathrm{mg}$ DW) and quercetin $(0.603 \pm 19.543 \mathrm{mg} / 100-\mathrm{mg}$ DW). Ferulic acid, bergapten, diosmin, hyperoside, isopimpinellin, luteolin 7-glucoside and trans resveratrol were not detected in our extract. 
Table 2. The contents in the phenolic compounds measured in the PAH extract.

\begin{tabular}{|c|c|c|c|}
\hline Bioactive Compounds & $\begin{array}{l}\lambda_{\max } \\
(\mathrm{nm})\end{array}$ & $\begin{array}{c}R_{\mathrm{T}} \\
(\mathrm{min})\end{array}$ & $\begin{array}{l}\text { PAH Extract } \\
\text { mg/100 mg DW }\end{array}$ \\
\hline \multicolumn{4}{|c|}{ Coumarins } \\
\hline 7-methoxycoumarin & 337 & 14.223 & $0.425 \pm 13.782$ \\
\hline Bergapten & 270 & 27.958 & N.D. \\
\hline Isopimpinelline & 270 & 18.706 & N.D. \\
\hline \multicolumn{4}{|c|}{ Flavonoids } \\
\hline $\begin{array}{l}\text { Delphinidin 3-rutinoside } \\
\text { chloride }\end{array}$ & 275 & 6.156 & $1.034 \pm 6.326$ \\
\hline Diosmin & 337 & 17.637 & N.D. \\
\hline Hyperoside & 360 & 15.333 & N.D. \\
\hline Luteoline 7-glucoside & 360 & 14.442 & N.D. \\
\hline Rutin & 360 & 15.780 & $0.094 \pm 15.766$ \\
\hline Quercetin & 360 & 19.543 & $0.603 \pm 19.543$ \\
\hline \multicolumn{4}{|c|}{ Phenolic acids } \\
\hline Caffeic acid & 326 & 7.445 & $0.092 \pm 7.433$ \\
\hline Chlorogenic acid & 326 & 6.705 & $0.076 \pm 6.528$ \\
\hline Ellagic acid & 254 & 16.862 & $0.393 \pm 16.630$ \\
\hline Ferulic acid & 326 & 10.799 & N.D. \\
\hline Gallic acid & 254 & 2.976 & $0.026 \pm 3.075$ \\
\hline Rosmarinic acid & 326 & 16.050 & $2.65 \pm 16.089$ \\
\hline Trans p-coumaric acid & 326 & 10.198 & $0.056 \pm 10.108$ \\
\hline \multicolumn{4}{|c|}{ Stilbenes } \\
\hline Trans resveratrol & 337 & 15.768 & N.D. \\
\hline
\end{tabular}

The results obtained showed the differences from the concentrations of bioactive compounds previously identified by other authors [12,46-48]. Other studies found in Polygonum aviculare L. species large amounts of phenolic compounds [49], the total quantity of the flavonoids being between 0.1 and $1 \%$ and, rarely, up to $2.5-3 \%$. The principal flavonoids identified were derivates of kaempferol, quercetin, myricetin and, particularly, avicularin (quercetin-3-O-arabinoside in a proportion of approximately $0.2 \%$ ), juglanin (kaempferol-3-O-arabinoside), rutin, apigenin, hyperoside and quercetin-3-galactoside, as well as vitexin and isovitexin. The differences found may probably be due to the pedoclimatic conditions in the area of origin of the plant materials.

\subsection{Bioactive Compound Content and Antioxidant Activity of PAH Extract}

Although all the phenolic compounds were measured, not all these compounds present in nature give the same response. The quantification by HPLC-PDA was wellcorrelated with the total polyphenolic content. However, the Folin-Ciocâlteu method usually results in higher readings when compared to other methods. The total polyphenols determined by Folin-Ciocâlteu and expressed as mg GAE/100-g dry extract (DW) identified in the PAH extract were $19.08 \pm 0.234$, while the total flavonoids were $0.676 \pm 0.753 \mathrm{mg}$ QE/100-g DW. The antioxidant capacity through the DPPH, CUPRAC and ABTS methods had high values compared to the other plant extracts studied. Thus, lyophilised PAH extract showed the following values of antioxidant activity measured by different methods: DPPH: $\mathrm{IC}_{50}=51.18 \mu \mathrm{g} / \mathrm{mL}$, ABTS: $70.98 \pm 1.20-\mathrm{mmol} \mathrm{TE} / \mathrm{g}$ DW, FRAP: $236.57 \pm 2.15-\mu \mathrm{mol}$ TE/g DW and CUPRAC $448.92 \pm 3.21-\mu \mathrm{mol}$ TE/g DW. Hsu [11] found in Polygonum aviculare L. extract powder a total flavonoid content of $112.7 \pm 13 \mu \mathrm{g} / \mathrm{g}$, while the total polyphenolics content was $677.4 \pm 62.7 \mu \mathrm{g} / \mathrm{g}$. The antioxidant activities examined by different methods showed a value of $\mathrm{IC}_{50}$ equal to $50 \mu \mathrm{g} / \mathrm{mL}$ in the free radical scavenging assay, $0.8 \mu / \mathrm{mL}$ in the superoxide radical scavenging analyses and 
$15 \mu \mathrm{g} / \mathrm{mL}$ in the lipid peroxidation assays, respectively [11]. These results confirmed a high content of active compounds and a good antioxidant capacity of the PAH extract.

\subsection{Preparation and Characterisation of Liposomes}

Six liposome formulations were prepared in the following way: two formulations of unloaded liposomes (L1 and L2), two formulations of liposomes loaded with quercetin (L3 and L4) and two formulations of liposomes loaded with the PAH extract. The composition of the liposome formulations is presented below in Table 1.

Taking into account that the liposomes stability is limited due to the tendency of phospholipids to get oxidised, they were stored in well-sealed tubes at temperatures of $4-8{ }^{\circ} \mathrm{C}$ after preparation [50]. A liposome's size affects its systemic distribution and clearance. The larger the liposome, the higher the risk of uptake and degradation by the reticuloendothelial system (RES). Based on the composition of phospholipids and the $\mathrm{pH}$ of the environment, liposomes can be negatively or positively charged or be neutral. The nature and density of the electrical charge on the surface of the liposomal membrane influences the stability and biodistribution kinetics, as well as the liposomal uptake by target cells [51].

Phosphatidylcholine-containing liposomes with a neutral charge have a lower chance of being recognised and destroyed by RES after administration. Phosphatidylserinebased liposomes are negatively charged and have a higher rate of endocytosis due to the recognition of the negatively charged surface by macrophage receptors. A small amount of lipids (cholesterol) was added to control the rigidity of the liposomal membrane and to reduce the instability caused by serum proteins binding to the membrane. Cholesterol is a common membrane constituent in biological systems, and it is involved in modulating the membrane fluidity, elasticity and permeability.

The size and zeta potential were measured using dynamic light scattering (DLS). The liposomes obtained with phosphatidylcholine and PAH extract (L5) were smaller than those obtained with phosphatidylcholine and quercetin (L3) but larger than those of bare liposomes (L1). The zeta potential is negative, and the lowest is quercetin liposomes $(-33.16 \mathrm{mV})$, followed by liposomes with the PAH extract $(-33.06 \mathrm{mV})$ and bare liposomes $(-10.6 \mathrm{mV})$. Liposomes obtained with phosphatidylserine and PAH extract (L6) have the smallest dimensions, followed by liposomes with phosphatidylserine and quercetin (L4) but are larger than bare liposomes (L2). The zeta potential is negative, and the lowest are the bare liposomes $(-29.8 \mathrm{mV})$, followed by those with the PAH extract $(-26.63 \mathrm{mV})$ and the liposomes with quercetin (L4).

The liposome size can range from very small $(25 \mathrm{~nm})$ to large $(2500 \mathrm{~nm})$ vesicles. Furthermore, liposomes may have a two-layer membrane. The size of the vesicle is a parameter used to assess the distribution of liposomes, and the number of layers affects the amount of entrapped substance. The liposomes with sizes between $100 \mathrm{~nm}$ and $1000 \mathrm{~nm}$ are considered gigantic liposomes, according to the literature. Taking into account the results obtained and the demonstrations of other research on liposome technology, we can say that the liposomes obtained by the method of hydration of the lipid film applied in the preparation determined the obtaining of multilamellar, giant liposomes. Among the advantages of this type of liposome are an increased stability and ease of preparation [52]. As a result, several unilamellar vesicles formed on the inside of them, making a multilamellar structure of concentric phospholipid spheres separated by water layers. To make the following studies on liposomes more efficient, a separation of them was performed by filtration using a 450-nm microfilter, and a uniformity of size for them was obtained.

It was noted that the zeta potential was lower for phosphatidylcholine liposomes compared to those formed with phosphatidylserine, although the methods of obtaining them were identical. The distribution of the sizes of the obtained liposomes determined by DLS was shown in Figure 1. 
a

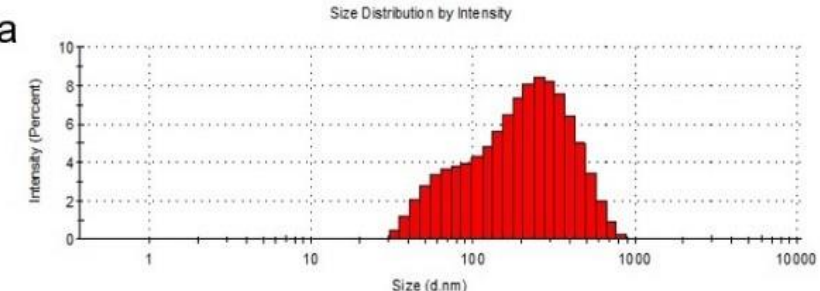

C

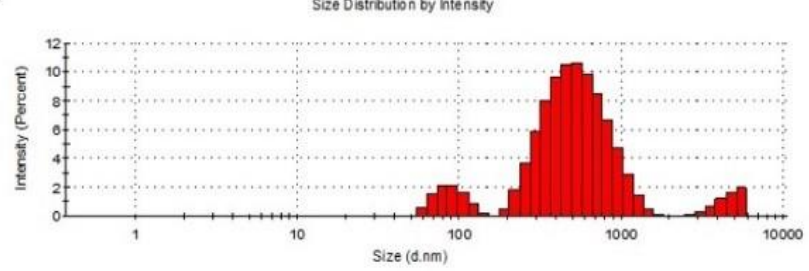

e

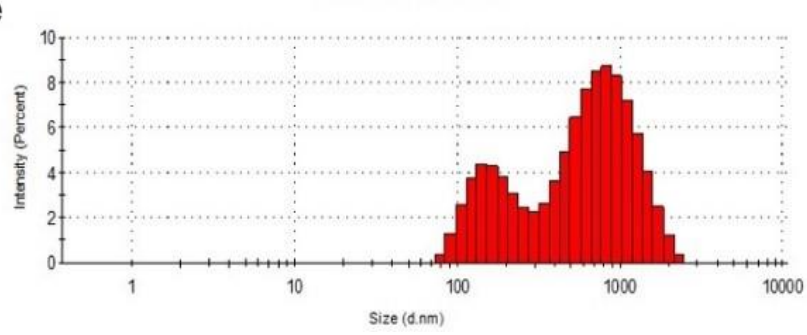

b

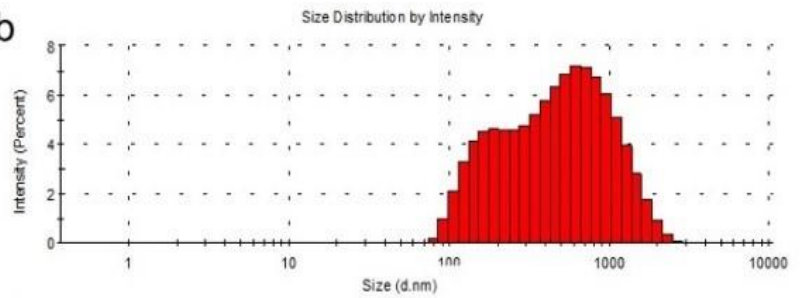

d

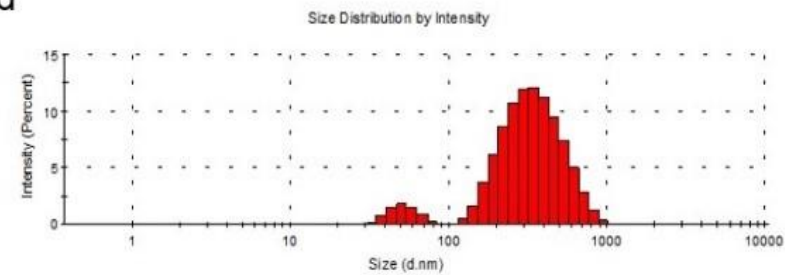

f

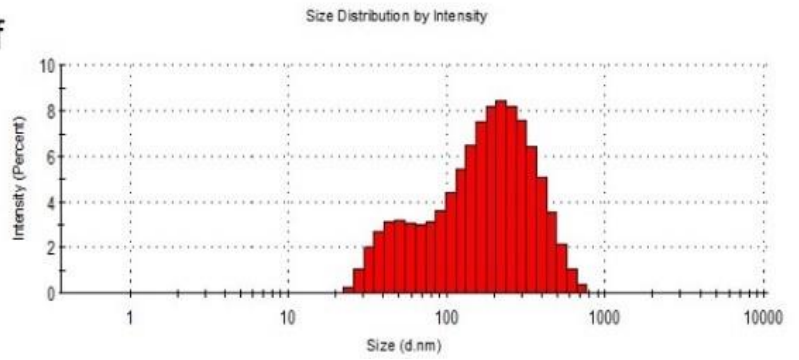

Figure 1. DLS analysis of the liposomal systems. Particle size distribution of the L1 (a), L2 (b), L3 (c), L4 (d), L5 (e) and L6 (f) formulations.

The entrapment of quercetin in liposomes with phosphatidylcholine and cholesterol led to an increase in the liposome diameter. When phosphatidylcholine was used for the preparation, the diameter of the liposomes increased, being between 100 and $1000 \mathrm{~nm}$ with a percentage of approximately $80 \%$ for L3 and 77\% for L5, compared to $78 \%$ for L1. The percentages of liposomes with a diameter of less than $100 \mathrm{~nm}$ also decreased from L1 $(22 \%)$ to L3 (2\%) and to L5 (1.5\%). Even if, at L1, the diameter of the liposomes did not exceed $1000 \mathrm{~nm}$, for the loaded liposomes, the diameter exceeded this value (L3-14\% and L5-20\%). In the preparation of liposomes with phosphatidylserine, the percentage of liposomes with a diameter of less than $100 \mathrm{~nm}$ increased from L2 (1\%) to L4 (4\%) and to L6 $(25 \%)$. It can also be seen that the diameter of bare liposomes (L2) exceeded $1000 \mathrm{~nm}$ by $15 \%$, this percentage decreasing to zero for loaded liposomes (L4 and L6), which means that the loading of liposomes with quercetin or PAH led to a decrease in their size. To make the following studies on liposomes more efficient, a separation of them was performed by filtration using a 450-nm microfilter and a uniformity of size for them was obtained. The particle size obtained was calculated from three sets of readings.

\subsection{Liposome Morphology Evaluated by AFM}

Liposome characterisation was performed by the AFM technique. Porous sphere morphology with micrometric dimensions is important in drug delivery systems. The main advantage of the AFM procedure is the possibility to operate with high resolution in the air or inside a fluid in real time and on a nanoscale [53].

The calculated values from the AFM images (average roughness (Sa), mean square root roughness $(\mathrm{Sq})$, maximum peak height $(\mathrm{Sp})$, maximum valley depth $(\mathrm{Sv})$ and maximum peak-to valley height (Sy)) are shown in Table 3. 
Table 3. Roughness results from the AFM images.

\begin{tabular}{|c|c|c|c|c|c|c|c|}
\hline Sample Name & $\begin{array}{c}\text { Area (Ironed Area) } \\
\qquad\left(\mu \mathrm{m}^{2}\right)\end{array}$ & $\begin{array}{c}\text { Sa } \\
(\mu \mathrm{m})\end{array}$ & $\begin{array}{c}\mathrm{Sq} \\
(\mu \mathrm{m})\end{array}$ & $\begin{array}{c}\mathrm{Sp} \\
(\mu \mathrm{m})\end{array}$ & $\begin{array}{c}\text { Sv } \\
(\mu \mathrm{m})\end{array}$ & $\begin{array}{c}\text { Sy } \\
(\mu \mathrm{m})\end{array}$ & Roughness \\
\hline L1 & 910 & 0.070 & 0.090 & 0.338 & -0.334 & 0.673 & + \\
\hline L2 & 912 & 0.099 & 0.126 & 0.473 & -0.395 & 0.868 & + \\
\hline L3 & 929 & 0.234 & 0.312 & 1.193 & -0.902 & 2.095 & +++ \\
\hline $\mathrm{L} 4$ & 931 & 0.301 & 0.404 & 1.320 & -1.034 & 2.354 & +++ \\
\hline L5 & 917 & 0.101 & 0.126 & 0.394 & -0.389 & 0.784 & ++ \\
\hline L6 & 905 & 0.087 & 0.108 & 0.368 & -0.294 & 0.663 & ++ \\
\hline
\end{tabular}

Sa-average roughness, Sq—mean square root roughness, Sp-maximum peak height, Sv—maximum valley depth and Sy—maximum peak-to-valley height.

The results from Table 3 confirmed that samples L4 and L3 exhibited the highest roughness, followed by L5 and L6, while the lowest roughness value was observed in the cases of L2 and L1. The samples presented irregular agglomerated formations with the exception of the more regular-shaped in the case of samples L3 and L4. The round formations were more "compact" and closer to each other in sample L4. The base (L1 and L2) had a more irregular surface (Figure 2A,B) compared to the L5 and L6 samples that exhibited well-shaped surfaces indicated by the profile analysis (Figure 2E,F). The surface profile should not be confused with the overall roughness, which was observed by the valleys and heights of the sample, while the profile is an indicator of the surface appearance in a certain area. In our case, a low roughness indicated the absence of a compound on the surface that can or cannot create a layer. Together with higher roughness results, it can be concluded that L5 and L6 interacted with the introduced compounds. The same conclusion is viable for $\mathrm{L} 3$ and $\mathrm{L} 4$, which had the highest roughness and most visible agglomerations (Figure 2C,D).

The connection between the zeta potential and the roughness of the surface has been reported in several works [54-56]. It should be noted that the particle shape and morphology, together with $\mathrm{pH}$, could also influence the zeta potential value $[54,55]$. In our study, the zeta potential has a negative value due to the accumulation of the charge carriers in certain areas as a result of the "backflow regions" that occurred as a consequence of different morphologies and, therefore, different asperities on the surface [55]. The area of the empty liposome formulas is smaller than that of the loaded ones, which means that both quercetin and the phytocomplex extracted from PAH were trapped. The morphological and structural characterisations of liposomes is important for their mode of action and gives an overview of their biological activity. Nanometrically modified surfaces promote adhesion by making possible the more natural bonding of bioactive nanoparticles to the cell membrane. 


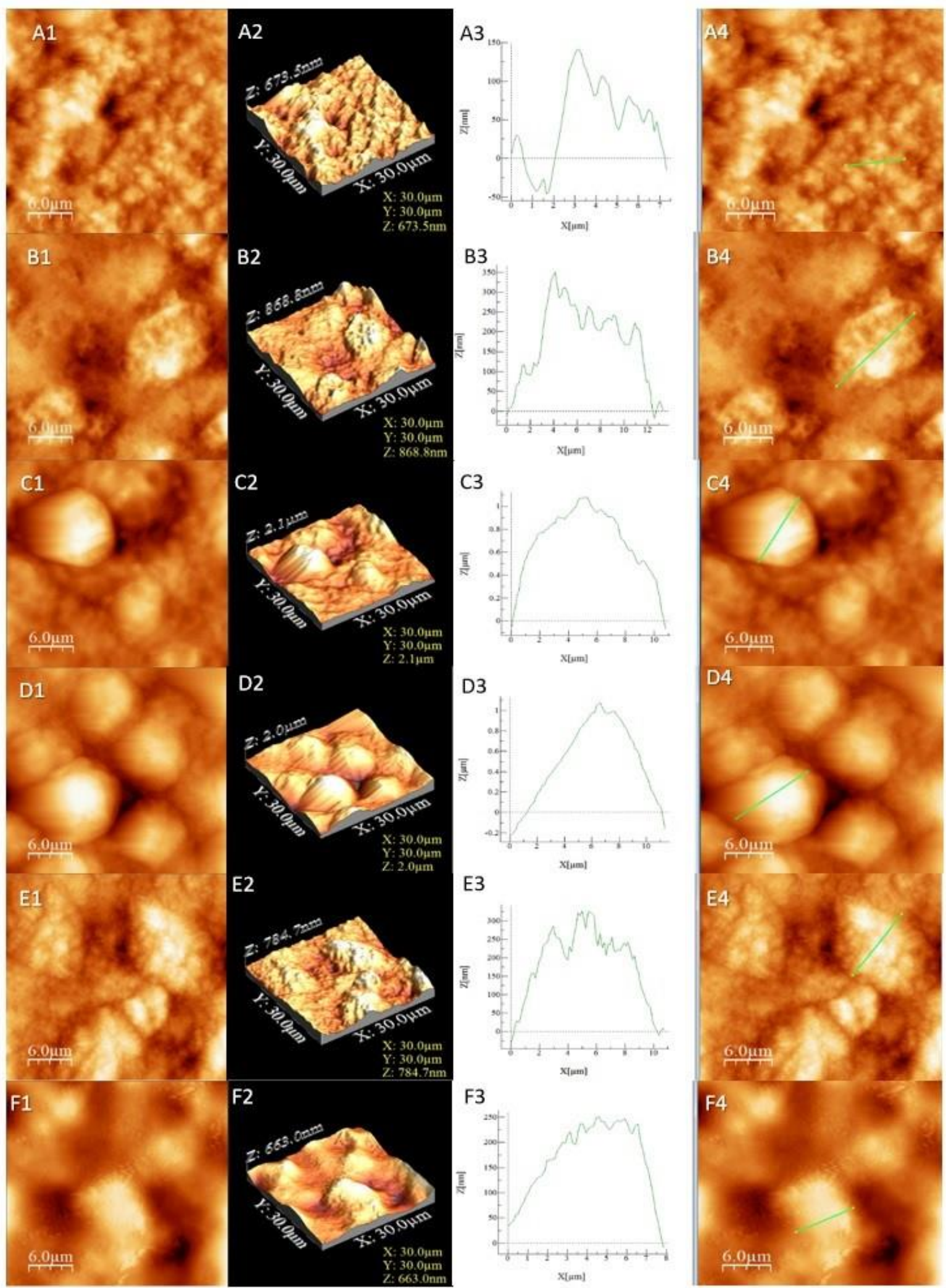

Figure 2. AFM images for the studied liposomes. The letters correspond to (A) L1, (B) L2, (C) L3, (D) L4, (E) L5 and (F) L6. The numbers correspond to (1) AFM image, (2) 3D image, (3) profile of the sample and (4) area selected for profiling. 


\subsection{Liposome Entrapment Efficiency}

Thanks to their bioactive substance content, liposomes guarantee the efficient transport to cells or tissues and the maintenance of a constant therapeutic concentration, reducing the risk of overdosing. Further investigations were needed in order to ascertain the utility of the formed liposomes. To this end, the degree of liposomal quercetin entrapment, as well as the total flavonoids from the PAH extract, were followed. The specimens showed good efficiency, as presented in Table 4 . These results confirmed the importance of hydrating the lipid film through the method chosen by us.

Table 4. The liposome entrapment efficiency at three different storage intervals.

\begin{tabular}{|c|c|c|c|c|}
\hline Liposome Specimens & $E E \%$ at the Time of Preparation & $\begin{array}{c}E E \% \\
\text { at } 10 \text { Days }\end{array}$ & $\begin{array}{c}E E \% \\
\text { at } 30 \text { Days }\end{array}$ & $\begin{array}{c}E E \% \\
\text { at } 60 \text { Days }\end{array}$ \\
\hline L3 & $85 \pm 2.01$ & $84.6 \pm 2.14$ & $83.8 \pm 0.97$ & $83 \pm 1.91$ \\
\hline L4 & $88.4 \pm 1.91$ & $88.2 \pm 2.03$ & $88 \pm 0.16$ & $87.8 \pm 0.75$ \\
\hline L5 & $79 \pm 1.07$ & $78.8 \pm 0.27$ & $78.7 \pm 0.64$ & $78.5 \pm 1.25$ \\
\hline L6 & $81 \pm 2.12$ & $80.8 \pm 1.24$ & $80.6 \pm 1.18$ & $80.5 \pm 1.54$ \\
\hline
\end{tabular}

$E E \%$ - entrapment efficiency.

We can specify the fact that the quercetin and PAH extract-loaded liposomes were stable after 60 days of storage at $4{ }^{\circ} \mathrm{C}$, with minimal losses.

\subsection{The Release of Flavonoids Entrapped in Liposomes Using a Franz Cell System}

In this experiment conducted with the diffusion method, the PAH extract and quercetin entrapped in the two types of liposomes were released in a variable degree after $12 \mathrm{~h}$. The results are shown in Figure 3. The quantity of PAH released was evaluated as a percent of the total released flavonoids expressed in QE. The total flavonoid quantity from the lipid formulations showed a slower release rate, as follows: L3 formulation- $80.05 \pm 3.45 \%$, L4 formulation- $-82.25 \pm 2.06 \%$, L5 formulation $-78.50 \pm 3.16 \%$ and L6 formulation-77.20 \pm $2.08 \%$. The initial release rate was $70 \%$ in the first $6 \mathrm{~h}$; after which, the concentration of the pharmacologically active ingredient was maintained. Moreover, it avoided uncontrolled substance release and allowed us to obtain a constant pharmacokinetic profile.

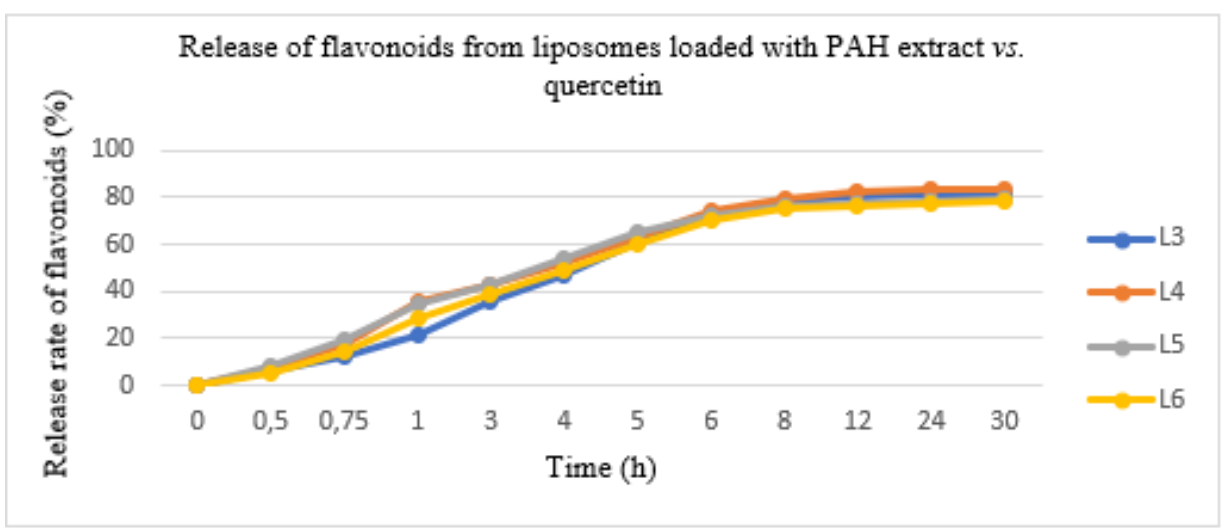

Figure 3. The release of flavonoids from liposomes loaded with the PAH extract (L5 and L6) vs. liposomes loaded with quercetin (L3 and L4).

In order to investigate the mechanism of the in vitro flavonoid release, several kinetic models were analysed (zero order, first order, Higuchi and Hickson-Crowell). The models were compared using $\left(\mathrm{R}^{2}\right)$ correlation. The data showed in vitro flavonoid release kinetics in concordance with the Higuchi model, which approximated the experimental measurements well. The resulting correlation quotient had a value of 0.9923 using KinetDS 3 rev 2010 software (version 3.0, Medyczna, Poland). 


\subsection{HUVECs Viability Assay}

In order to establish the influence of free quercetin, the PAH extract and different formulations of liposomes with quercetin or the PAH extract on the HUVEC viability in the presence of Doxo, the MTS assay was performed. The cell viability was evaluated after exposure to different concentrations of quercetin and the L3 and L4 formulations (ranged between $0.001 \mu \mathrm{g} \mathrm{GAE} / \mathrm{mL}$ and $100-\mu \mathrm{g}$ GAE/mL) (Figure 4). For the PAH extract or $\mathrm{L} 5$ and $\mathrm{L} 6$ formulations, the concentrations used varied between $0.006 \mathrm{GAE} / \mathrm{mL}$ and $0.678 \mu \mathrm{g}$ GAE$/ \mathrm{mL}$. Quercetin induced a slight viability decrease at doses above $0.1 \mu \mathrm{g} / \mathrm{mL}$, while both formulations of liposomes with quercetin increased the cellular viability even at $100 \mu \mathrm{g} / \mathrm{mL}$, especially the L3 formulation (Figure 4). The PAH extract led to significant changes in the cell viability above $0.33-\mu \mathrm{g}$ GAE $/ \mathrm{mL}$ compared to the control. The L5 formulation reduced the viability at doses exceeding $0.06 \mu \mathrm{g} / \mathrm{mL}$ (Figure 4), while L6 significantly decreased the cell viability, starting at $0.006 \mu \mathrm{g} / \mathrm{mL}$ (Figure 4). The decline of viability was dose-dependent in the presence of L5 and L6, while the L3 and L4 formulations increased the cellular viability of the HUVEC cells even at high doses. The different behaviours of the various formulations of liposomes depended on their composition and the compounds loaded. Starting from the viability test, the concentrations chosen for further experiments were $0.01-\mu \mathrm{g} \mathrm{GAE} / \mathrm{mL}$ for all tested compounds.
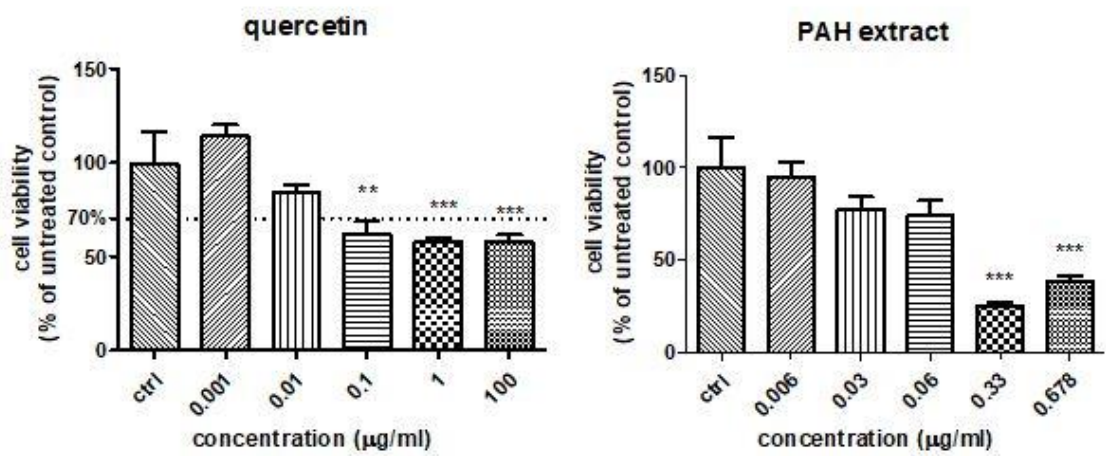

L3
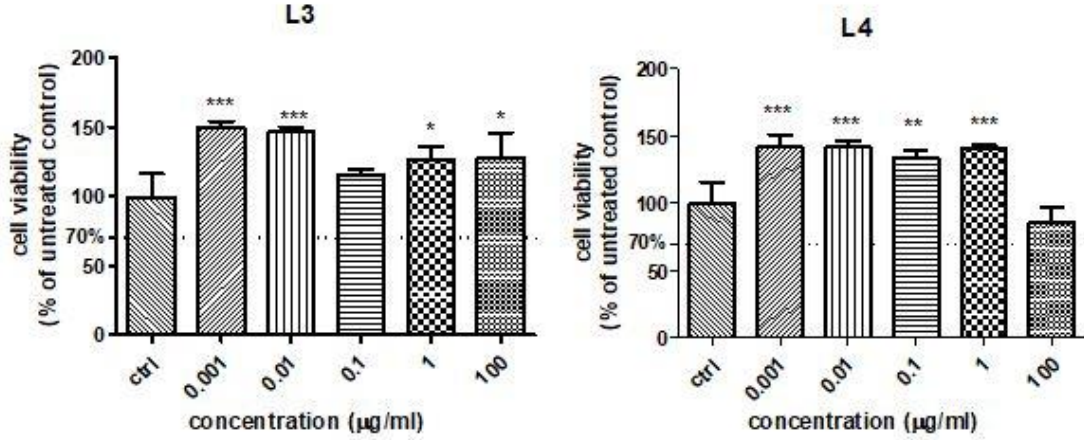

L5
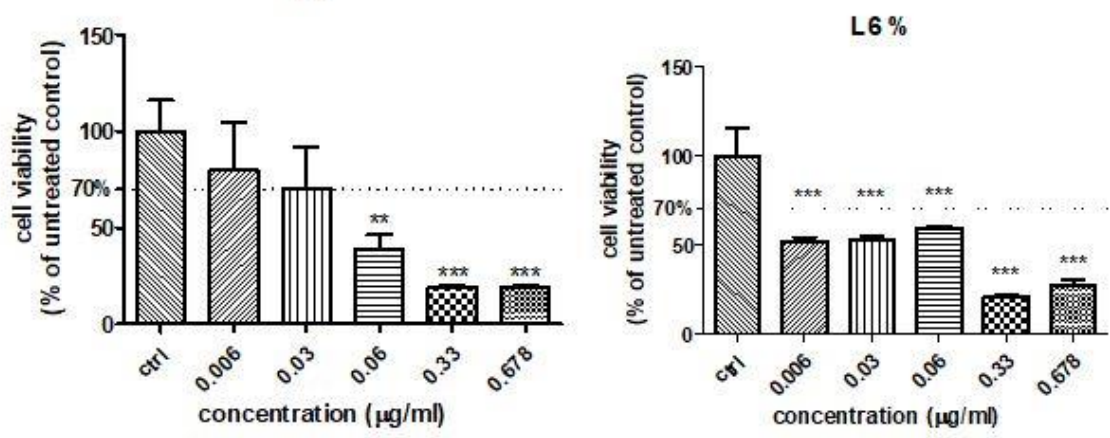

Figure 4. Cell viability of HUVECs treated with quercetin, PAH extract and different liposome 
formulations with quercetin and the PAH extract. HUVECs were exposed to quercetin and L3 and L4 formulations in concentrations ranging between $0.001-\mu \mathrm{g} \mathrm{GAE} / \mathrm{mL}$ and $100-\mu \mathrm{g} \mathrm{GAE} / \mathrm{mL}$ and to the PAH extract and L5 and L6 formulations in concentrations between 0.006- $\mu \mathrm{g} \mathrm{GAE} / \mathrm{mL}$ and $0.678-\mu \mathrm{g}$ GAE $/ \mathrm{mL}$ (data are presented as the mean of OD540 $\pm \mathrm{SD} ; n=3$ for each sample). ${ }^{*} p<0.05$, ** $p<0.01$ and ${ }^{* * *} p<0.001$ vs. control, untreated cells.

\subsection{Evaluation of Biological Activities on HUVECs Exposed to Doxo}

In order to explore the mechanisms involved in the protection of quercetin, the PAH extract and different formulations of liposomes with quercetin and the PAH extract, an in vitro model of toxicity induced by Doxo administration on the HUVEC cell line was used. The toxicity of Doxo was assessed by malondialdehyde in cell lysates, cytokine IL-6 and caspases levels in the cellular medium and, also, by the quantification of DNA lesions and transcription factors in endothelial cells.

MDA increased in cell lysates after Doxo exposure $(p<0.001)$ and diminished significantly both after PAH extract and quercetin administration $(p<0.001)$ compared to the control cells (Figure 5A). The two formulations of liposomes with quercetin (L3 and L4) reduced the MDA levels, the best results being obtained after the L3 treatment $(p<0.001)$ if the results were compared to those obtained after the L4, L5 and L6 administrations. The liposomes loaded with the PAH extract decreased the lipid peroxidation $(p<0.001)$ without a significant difference between PAH and two forms of liposomes with the PAH extract (L5 and L6) (Figure 5A).

The inflammation induced by Doxo was assessed by IL-6 secretion in the supernates of cells exposed to quercetin, PAH extract and different liposomes formulations. The IL-6 levels increased significantly in the supernates of cells treated with Doxo and diminished after the PAH extract $(p<0.001)$, L3 $(p<0.001)$, L4 $(p<0.001)$, L5 $(p<0.001)$ and L6 $(p<0.05)$ administrations. The anti-inflammatory effect was comparable between the PAH extract and L3 formulation (Figure 5B).

To evaluate the effect of quercetin, the PAH extract and various formulations of liposomes on apoptosis, caspases-3, -8 and -9 were evaluated in the supernates of cells exposed to Doxo (Figure 6). Thus, Doxo administration increased the apoptotic index $(p<0.001)$, while the PAH extract diminished the caspase-9 $(p<0.001)$ and $-8(p<0.01)$ levels. The liposomes loaded with PAH extract reduced caspases-3 and -9, especially the L6 formulation $(p<0.001)$. Quercetin administered in cells incubated with Doxo significantly decreased all caspases in the supernates $(p<0.001)$. The same effect was obtained after the L3 liposomes prepared with quercetin $(p<0.001)$.

A

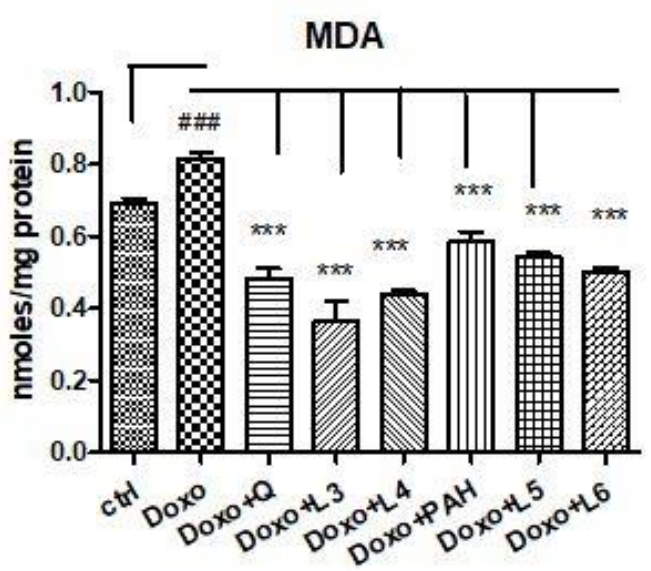

B

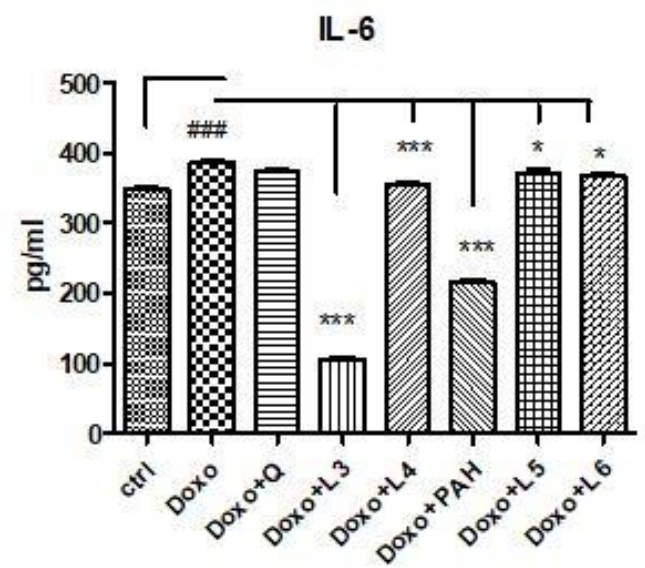

Figure 5. Malondialdehyde levels in the cell lysates, and IL-6 secretion in the supernates of the 
HUVECs exposed to Doxo and quercetin, the PAH extract and different formulations of liposomes. (A) MDA increased significantly after Doxo administration and diminished in the cells treated with quercetin $(p<0.001)$, the PAH extract $(p<0.001)$, L3 and L4 with quercetin $(p<0.001)$ and L5 and L6 with the PAH extract $(p<0.001)$. (B) IL-6 secretion increased after Doxo exposure $(p<0.001)$ and diminished in the supernates of the cells treated with L3, L4 $(p<0.001)$, L5 and L6 $(p<0.05)$. The statistical significance of the differences between the treated and control groups was evaluated with one-way ANOVA, followed by Dunnett's multiple range test. Data are presented as the mean and SD of triplicate samples. ${ }^{\# \#}$ vs. control and ${ }^{*} p<0.05 ;{ }^{* * *} p<0.001$ vs. Doxo-treated cells.

A

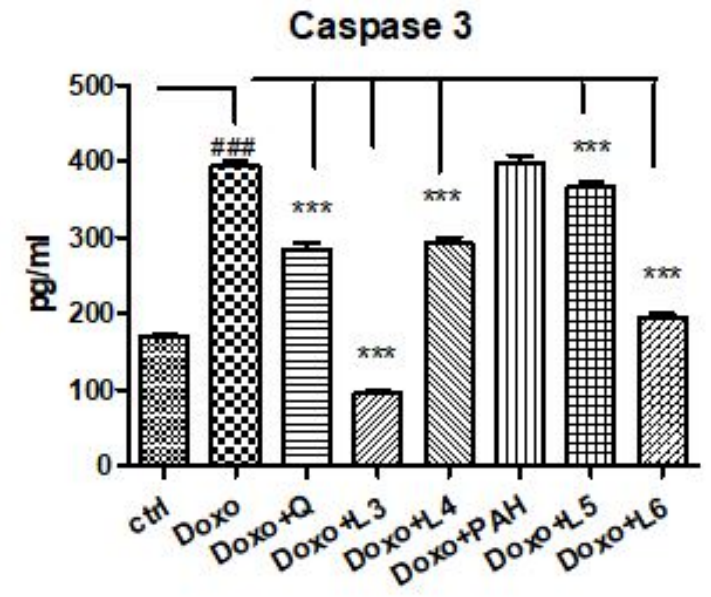

C

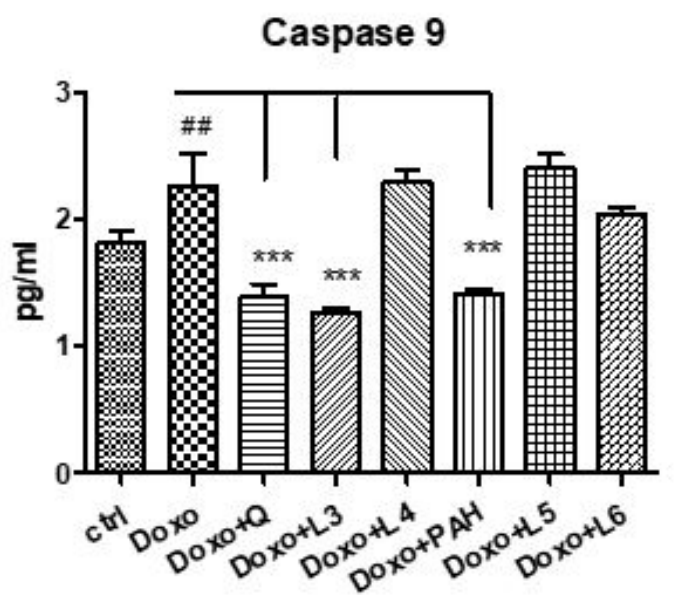

B

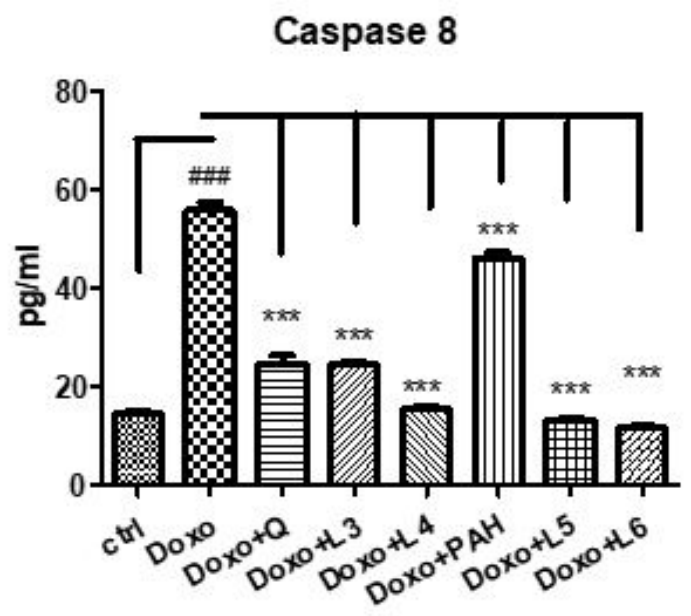

Figure 6. Caspases-3, -8 and -9 in the supernates of HUVEC exposed to Doxo and quercetin, the PAH extract and different liposomes formulations. Caspases-3 (A), -8 (B) and -9 (C) increased significantly after Doxo exposure and diminished both in cells treated with quercetin $(p<0.001)$ and L3 $(p<0.001)$. The PAH extract significantly reduced caspase- 8 and caspase- 9 $(p<0.001)$, while L5 and L6 decreased the caspase-3 and caspase- 8 levels $(p<0.001)$. The statistical significance of the difference between the treated and control groups was evaluated with one-way ANOVA, followed by Dunnett's multiple range test. Data are presented as the mean and SD of triplicate samples. ${ }^{\# \#} p<0.01$; ${ }^{\# \#} p<0.001$ vs. control and ${ }^{* * *} p<0.001$ vs. Doxo-treated cells.

In our experimental design, Doxo exposure significantly induced Nrf2 $(p<0.05)$ and NF-kB activation $(p<0.01)$ without affecting the DNA in the administered dose 
(Figure 7A-C). The expression of constitutive NF-kB and the phosphorylated form pNF-kB quantified by Western blotting showed NF-kB activation after the L3 treatment $(p<0.01)$, while the L4 and L5 formulations downregulated the pNF-kB/NF-kB ratio $(p<0.05)$. The DNA lesions quantified by $\gamma \mathrm{H} 2 \mathrm{AX}$ expression in cell lysates were reduced after quercetin $(p$ $<0.001)$ and the liposomes loaded with quercetin, especially L4 $(p<0.001)$, and, also, after PAH and the liposomes loaded with PAH (L5: $p<0.001$ ) (Figure 7D). The best protection was found in the cells treated with the L4 formulation.
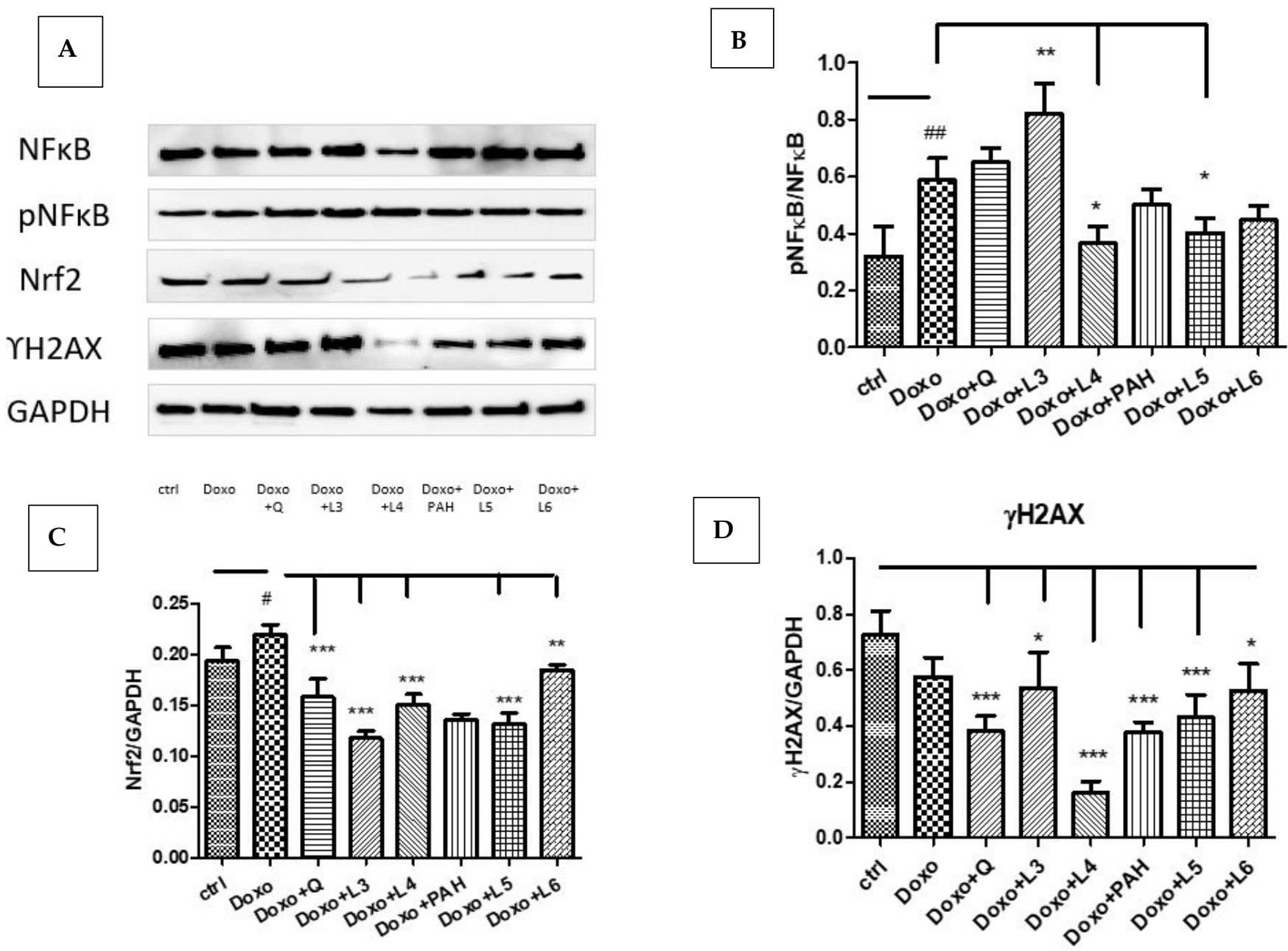

Figure 7. NF-kB, pNF-kB, Nrf2 and $\gamma \mathrm{H} 2 \mathrm{AX}$ expressions in HUVEC lysates after exposure to Doxo and the treatments with quercetin; the PAH extract and the L3, L4, L5 and L6 formulations. Representative images of immunoblotting for NF-kB, pNF-kB, Nrf2, $\gamma \mathrm{H} 2 \mathrm{AX}$ and GAPDH in the HUVEC s treated with quercetin, the PAH extract and liposomes loaded with quercetin and the PAH extract are shown in the upper panel (A), and the results of the statistical analysis for the ratio of Nrf2, $\gamma \mathrm{H} 2 \mathrm{AX}$ and GAPDH expressions are in the lower panels (C,D). For NF-kB and pNF-kB, the results were expressed as pNF-kB divided by the total NF-kB (B). The statistical significance of the differences between treated and control groups was evaluated with one-way ANOVA, followed by Dunnett's multiple range test; ${ }^{\#} p<0.05$; ${ }^{\# \#} p<0.01$ vs. control cells and ${ }^{*} p<0.05 ;{ }^{* *} p<0.01 ;{ }^{* * *} p<0.001$ vs. Doxo-treated cells.

In the last years, there have been numerous studies on Doxo cytotoxicity, particularly on cardiomyocytes, but the mechanisms responsible are not completely elucidated. The cytotoxic effects were related especially to easy diffusion in the intracellular environment, the intercalation in DNA and the inhibition of topoisomerase II with the reduction of cell division and growth $[57,58]$. Moreover, Doxo induced mitochondrial dysfunction due to the accumulation of drugs inside the mitochondria and generated considerable quantities of reactive oxygen species (ROS) $[59,60]$. ROS production is responsible for 
macromolecules oxidation, including myofibrillar proteins and the induction of muscular dysfunction [18,61].

Doxo is converted to a radical by various mechanisms, particularly in the presence of iron released from aconitase or ferritin [62,63]. When antioxidant enzymes are exceeded, the superoxide anion forms peroxynitrite, cytotoxic compounds for lipids, proteins and nucleic acids [64]. The mitochondrial damage triggers the activation of caspases and downregulates the B-cell lymphoma (Bcl)-2 protein expression [65], key factors involved in apoptosis. Additionally, Doxo can directly damage the DNA by the inhibition of topoisomerase II, an enzyme implicated in DNA repair, and subsequently, DNA aggregation and breakage occur, especially after high doses.

Moreover, in the systemic administration of Doxo, the first contact is with the vascular endothelium, where the drug can generate endothelial dysfunction, hyperpermeability due to the damage of the tight junction between endothelial cells, haemorrhage, atherosclerosis and restenosis $[19,26]$. Therefore, the strategy that provides the protection of the vascular endothelium can improve the cardio protection and reduce the risk of developing cardiomyopathy after Doxo administration.

The antioxidant effect of the tested compounds, especially of liposomes loaded with free quercetin and the PAH extract, can afford a good protection against oxidative stressinduced toxicity and, accordingly, against the activation of cellular pathways involved in inflammation and cell death. In our study, both free quercetin and liposomes loaded with quercetin inhibited oxidative stress and nonspecific inflammation and reduced DNA lesions and apoptosis. In parallel, these compounds diminished Nrf2 and NF-kB expressions, particularly the L4 formulation. The PAH extract and liposomes loaded with the PAH extract exerted an antioxidant activity, diminished the secretion of proinflammatory cytokine and $\gamma \mathrm{H} 2 \mathrm{AX}$ formation and reduced extrinsic apoptosis. L5 and L4 inhibited Nrf2 and NF-kB activation, while L3 increased the pNF-kB expression. These effects were correlated with the high content of flavonoids or phenolic acids in the extract and a good antioxidant capacity evaluated by DPPH, ABTS, FRAP and CUPRAC.

Our results on the antioxidant activities of the PAH extract were in agreement with other findings found in the in vitro and in vivo experiments. Thus, Wu et al. [66] found that Polygonum orientale flower extract had a protective effect on $\mathrm{H}_{2} \mathrm{O}_{2}$-induced HUVEC cell injury by the inhibition of MDA formation and downregulation of Bcl-2 expression, while Polygonum multiflorum increased the activities of superoxide dismutase and glutathione peroxidase [67]. Doxo reduced the activities of catalase and superoxide dismutase 1 and 2, while the Polygonum maritimum extract improved the activity of these enzymes in cancer cells [68]. The anti-inflammatory effect of other species of Polygonum was demonstrated by Bralley et al. [69] on a mouse ear inflammation model induced by the topical application of 12-O-tetradecanoylphorbol-13-acetate (TPA). The Polygonum extract reduced the oedema and infiltration with neutrophils in the treated ear, the effect comparable with Indomethacin but without side effects. Therefore, the entrapment of the PAH extract in liposomes as carriers in order to increase the cell penetration and protection efficacy is a good strategy for the delivery of bioactive compounds to target cells.

It is known that chemotherapy with Doxo can induce dose-dependent endothelial dysfunction due to the reduction of vasodilators bioavailability - in particular, nitric oxidein parallel with increasing the vasoconstrictor agents [70]. In this process, NF-kB plays an important role as the transcription factor involved in cell proliferation, inflammation and differentiation as a response to oxidative stress [71]. Generally, free radicals generated by Doxo administration determine the NF-kB translocation into the nucleus and upregulation of different pathways [72]. El-Agamy et al. [73] demonstrated that Nrf2 and NF-kB inhibition by Pristimerin reduced the cardiotoxicity triggered by Doxo, while $\mathrm{Xu}$ et al. [71] found high expressions of p53 and phosphorylated p53 in Doxo heart rat vessels compared to untreated vessels. These findings confirmed the translocation of p53 into the nucleus after a Doxo treatment and NF-kB pathway activation and, also, its involvement in cardiac fibrosis [74]. It seems that the relationship between the activation of NF-kB 
and apoptosis is a complex, dual one, in which NF-kB can promote or inhibit apoptosis, depending on the type of cells or the nature of the stimuli [75]. Thus, in various cancer cells, Doxo-induced apoptosis is associated with the inhibition of NF-kB activation, suggesting the antiapoptotic role of NF-kB [76]. In our study, liposomes loaded with quercetin (L3) activated NF-kB, while oxidative stress and inflammation were inhibited. Moreover, L3 diminished the activity of the caspases, suggesting its antiapoptotic, antioxidant and anti-inflammatory properties. Probably, NF-kB activation induced by different stimuli upregulated the expression of genes involved in the resistance to cell death [77], including antiapoptotic proteins [78] and antioxidant enzymes. This mechanism was demonstrated both in different normal cells, such as primary rat and human fibroblasts, Jurkat $\mathrm{T}$ cells and in tumour cells of bladder cancer or breast carcinoma $[79,80]$. These data attested the dual role of NF-kB in promoting cell survival depending on the context, cells and experimental conditions [81].

It was demonstrated that a redox imbalance was associated with the nuclear translocation of Nrf2 and targeting genes of the antioxidant response element (ARE) region, such as heme oxygenase-1 (HO-1), NADPH dehydrogenase quinone 1 (NQO1) and g-glutamyl cysteine ligase [82]. Nrf2 activation reduced the inflammatory response and the subsequent inhibition of NF-kB signalling, while its inhibition increased the NF-kB activation and production of proinflammatory cytokines [83]. In our experiment, both quercetin and liposomes with quercetin, as well as the PAH extract and liposomes with the PAH extract, significantly diminished the expression of Nrf2 $(p<0.001)$ in cells exposed to Doxo in parallel with the inhibition of oxidative stress and inflammation.

The Nrf 2 activation in cancer cells reduced the chemotherapeutic toxicity by improving the antioxidant enzyme system and dropping the apoptosis but, at the same time, mediated the chemoresistance and allowed tumour cells to survive [84]. Unlike the dual effect of Nrf2 in tumour cells, in normal ones, the downregulation of Nrf2 is protective and ameliorates the Doxo-mediated cardiac and vascular toxicity triggered by oxidative stress. Doxo enhanced the Nrf2 expression and upregulated the superoxide dismutase, catalase and glutathione peroxidase activities. In our study, all the tested liposomes reduced the Nrf2 expression induced by Doxo and maintained low levels of ROS, suggesting their beneficial effect in vascular protection.

Additionally, oxidative stress is associated with the loss of mitochondrial membrane potential, cytochrome $\mathrm{C}$ release and apoptosis induction. Therefore, the agents that reduce oxidative, inflammation and apoptosis can be beneficial in cardio and vascular protection. Both quercetin and liposomes formulation with quercetin, particularly L3, diminished the caspases, while only liposomes loaded with the PAH extract had protective properties against apoptosis triggered by Doxo, especially extrinsic apoptosis. These results were consistent with the other literature data. Accordingly, the cardioprotective effect of quercetin was demonstrated in an in vitro experimental model on $\mathrm{H} 9 \mathrm{c} 2$ cell lines subjected to hypoxia/reoxygenation. Thus, a pretreatment with $10-16 \mu \mathrm{M}$ of quercetin resulted in a beneficial effect on cardiomyocytes by c-Jun N-terminal kinase and p38 mitogen-activated protein kinase inhibition and the modulation of proapoptotic protein Bcl-2 and Bax expressions [85]. Quercetin encapsulated in poly (lactic-co-glycolic acid) nanoparticles exerted a better cardioprotective action compared to free quercetin on the same experimental model due to decrease in the ROS production and by the improvement of the mitochondrial function and ATP synthesis [86].

Co-delivered quercetin and Doxo by using a nanocarrier composed of methoxy poly(ethylene glycol) and poly(D, L-lactide-co-glycolide) (mPEG-PLGA NPs) exerted good protection on normal vascular endothelial cells and enhanced the antitumour effect of Doxo [87]. Quercetin increased the Nrf2 mARN expression and maintained the integrity of the cell membrane and, also, the histological abnormalities induced by Doxo exposure in rats [88]. These results confirmed the superior protective properties after the inclusion of quercetin in nanocarriers. It is known that quercetin is an effective antioxidant with a protective effect on ROS-induced damage [89], but due to a poor aqueous solubility 
and poor dissolution in gastrointestinal fluids, the intestinal absorption is reduced and its effect much diminished [90]. To improve the solubility, quercetin was added to liposomes that were able to carry and transport it due to the lipid bilayer and aqueous core [91]. In our study, the incorporation of quercetin into liposomes increased their antioxidant and anti-inflammatory efficacy, especially those formulated with phosphatidylcholine (L3), and inhibited apoptosis. In addition, quercetin, the PAH extract and liposomes loaded with two compounds inhibited the $\gamma \mathrm{H} 2 \mathrm{AX}$ foci formation enhanced by Doxo, suggesting its protective activity on DNA lesions. $\mathrm{\gamma H} 2 \mathrm{AX}$ is a marker that reflects the persistence of irreparable DNA double-stranded brakes after cell exposure to different genotoxic agents [90] and is frequently used to quantify DNA damage. In our experiment; irreversible DNA damage was reversed efficiently by all the tested compounds, and the best protection was exerted by the L4 liposomes.

\section{Conclusions}

In conclusion, this study provided evidence of the mechanisms involved in the endothelial toxicity of Doxo and brought up arguments for the endothelial protection of liposomes loaded with quercetin and the PAH extract. Doxo administration decreased the cell viability and induced oxidative stress, inflammation, DNA lesions and apoptosis in parallel with the activation of Nrf2 and NF-kB. Endothelial protection by the tested compounds was different depending on the liposomes formulation and the active substance used for loading. Thus, the best protection was exerted by liposomes prepared with phosphatidylcholine, especially those entrapped with quercetin. Both formulations of liposomes loaded with quercetin inhibited oxidative stress and nonspecific inflammation and reduced the DNA lesions and apoptosis. Additionally, these compounds diminished the Nrf2 and NF-kB expressions-principally, the L4 formulation-while L3 increased the NF-kB activation as a mechanism of cell survival.

The PAH extract and liposomes loaded with the PAH extract exerted antioxidant and anti-inflammatory activities, diminished the DNA lesions and inhibited extrinsic apoptosis and the activation of the transcription factors but to a lesser extent than quercetin and the liposomes with quercetin. These different results can be explained by different compositions and different behaviours of the liposomes in vitro. Certainly, the factors involved are varied and include how liposomes reach and act in a living cell, as well as the mechanisms by which they interfere. Therefore, further investigations are necessary for the evaluation of the biological effects of the extract and liposomes with the extract on endothelial cells and cardiomyocytes to maximise their benefits in cardio protection and vascular protection.

Author Contributions: Conceptualisation and writing—original draft preparation, M.M.; methodology, investigation and visualisation, D.O. and P.S.; conceptualisation, writing the paper and validation, G.A.F.; supervision and resources, S.C.; investigation and formal analysis, I.B.; methodology, T.J.; the investigation and interpretation of data, A.P.; data curation, E.M.; software and validation, A.F.; visualisation and funding acquisition, F.G.G.; funding acquisition and conceptualisation, B.S. and writing-review and editing, L.V. All authors have read and agreed to the published version of the manuscript.

Funding: This research received no external funding.

Institutional Review Board Statement: No applicable.

Informed Consent Statement: Not applicable.

Data Availability Statement: No applicable.

Acknowledgments: We thank Nicoleta Decea for the assessment of the biochemical parameters and Ioana Robu for the English language assistance.

Conflicts of Interest: The authors declare no conflict of interest. 


\section{References}

1. Yang, Y.; Zhang, T. Antimicrobial activities of tea polyphenols and phytopathogens: A review. Molecules 2010, 24, 816. [CrossRef]

2. Georgescu, C.; Bratu, I.; Tamas, M. The study of some polyphenols of Rhododendron kotschyi. Rev. Chim. 2005, 56, 779-780.

3. Koch, W. Dietary polyphenols-Important non-nutrients in the prevention of chronic noncommunicable diseases. A systematic Review. Nutrients 2019, 11, 1039. [CrossRef]

4. Martin, K.R.; Appel, C.I. Polyphenols as dietary supplements: A double-edged sword. Nutr. Diet. Suppl. 2010, 2, 1-12. [CrossRef]

5. Pralhad, T.; Rajendrakumar, K. Study of freeze-dried quercetin-cyclodextrin binary systems by DSC, FT-IR, X-ray diffraction and SEM analysis. J. Pharm. Biomed. Anal. 2004, 34, 333-339. [CrossRef]

6. Ragelle, H.; Crauste-Manciet, S.; Seguin, J.; Brossard, D.; Scherman, D.; Arnaud, P.; Chabot, G.G. Nanoemulsion formulation of fisetin improves bioavailability and antitumour activity in mice. Int. J. Pharm. 2012, 427, 452-459. [CrossRef] [PubMed]

7. Seguin, J.; Brulle, L.; Boyer, R.; Lu, Y.M.; Ramos, R.M.; Touil, Y.S.; Scherman, D.; Bessodes, M.; Mignet, N.; Chabot, G.G. Liposomal encapsulation of the natural flavonoid fisetin improves bioavailability and antitumor efficacy. Int. J. Pharm. 2013, 444, 146-154. [CrossRef]

8. Peng, S.; Zou, L.; Zhou, W.; Liu, W.; Liu, C.; Mc Clements, D.J. Encapsulation of lipophilic polyphenols into nanoliposomes using pH-driven method: Advantages and disadvantages. Agric. Food Chem. 2019, 67, 7506-7511. [CrossRef]

9. Habibi, R.M.; Mohammadi, R.A.; Delazar, A.; Halabian, R.; Soleimani, R.J.; Mehdipour, A.; Bagheri, M.; Najafabadi, A.J. Effects of polygonum aviculare herbal extract on proliferation and apoptotic gene expression of MCF-7. Daru 2011, 19, 326-331.

10. Sârbu, I.; Stefan, N.; Oprea, A. Plante Vasculare din România-Determinator Ilustrat de Teren; Editura Victor B Victor: Bucharest, Romania, 2013.

11. Hsu, C.Y. Antioxidant activity of extract from Polygonum aviculare L. Biol. Res. 2006, 39, 281-288. [CrossRef]

12. Granica, S.; Czerwińska, M.E.; Żyżyńska-Granica, B.; Kiss, A.K. Antioxidant and anti-inflammatory flavonol glucuronides from Polygonum aviculare L. Fitoterapia 2013, 91, 180-188. [CrossRef] [PubMed]

13. Pallag, A. Botanica Farmaceutică, Sistematica-Cormobionta; Oradea University: Oradea, Romania, 2015.

14. Kupczyński, R.; Szummy, A.; Bednarski, M.; Piasecki, T.; Śpitalniak-Bajerska, K.; Roman, A. Application of Pontentilla Anserine, Polygonum aviculare and Rumex Crispus mixture extracts in a rabbit model with experimentally induced E. coli infection. Animals 2019, 9, 774. [CrossRef] [PubMed]

15. Park, S.H.; Jang, S.; Son, E.; Lee, W.; Park, S.D.; Sung, Y.Y.; Kim, H.K. Polygonum aviculare L. extract reduces fatigue by inhibiting neuroinflammation in restraint-stressed mice. Phytomedicine 2018, 42, 180-189. [CrossRef] [PubMed]

16. Salama, H.M.H.; Najat Marraiki, N. Antimicrobial activity and phytochemical analyses of Polygonum aviculare L. (Polygonaceae), naturally growing in Egypt. Saudi J. Biol. Sci. 2010, 57-63. [CrossRef]

17. Bonadonna, G.; Monfardini, S.; De Lena, N.; Fossati-Bellani, F. Clinical evaluation of adriamycin, a new antitumour antibiotic. Br. Med. J. 1969, 3, 503-506. [CrossRef]

18. Gorini, S.; De Angelis, A.; Berrino, L.; Malara, N.; Rosano, G.; Ferraro, E. Chemotherapeutic drugs and mitochondrial dysfunction: Focus on doxorubicin, trastuzumab and sunitinib. Oxid. Med. Longev. 2018, 7582730. [CrossRef]

19. Wojcik, T.; Szczesny, E.; Chlopicki, S. Detrimental effects ofchemotherapeutics and other drugs on the endothelium: A call for endothelial toxicity profiling. Pharmacol. Rep. 2015, 67, 811-817. [CrossRef] [PubMed]

20. Vejpongsa, P.; Yeh, E.T. Prevention of anthracycline-induced cardiotoxicity: Challenges and opportunities. J. Am. Coll. Cardiol. 2014, 64, 938-945. [CrossRef]

21. Angsutararux, P.; Luanpitpong, S.; Issaragrisil, S. Chemotherapy-induced cardiotoxicity: Overview of the roles of oxidative stress. Oxid. Med. Cell Longev. 2015, 795602. [CrossRef] [PubMed]

22. Barancik, M.; Gresova, M.L.; Bartekova, M.; Dovinova, L. Nrf2 as a key player of redox regulation in cardiovascular diseases. Physiol. Res. 2006, 65, S1-S10.

23. Papaiahgari, S.; Zhang, Q.; Kleeberger, S.R.; Cho, H.Y.; Reddy, S.P. Hyperoxia stimulates an Nrf2- ARE transcriptional response via ROS-EGFR-PI3K-Akt/ERK MAP kinase signaling in pulmonary epithelial cells. Antioxid. Redox Signal. 2006, 8, 43-52. [CrossRef]

24. Abushouka, L.A.; Ismailb, A.; Salema, A.M.A.; Afifia, A.M.; Abdel-Daimd, M.M. Cardioprotective mechanisms of phytochemicals against doxorubicin-induced cardiotoxicity. Biomed. Pharm. 2017, 90, 935-946. [CrossRef] [PubMed]

25. Wang, S.; Kotamraju, S.; Konorev, E.; Kalivendi, S.; Joseph, J.; Kalyanaram, B. Activation of nuclear factor-kappaB during doxorubicin-induced apoptosis in endothelial cells and myocytes is pro-apoptotic: The role of hydrogen peroxide. J. Biochem. 2002, 367, 729-740. [CrossRef] [PubMed]

26. Soultati, A.; Mountzios, G.; Avgerinou, C.; Papaxoinis, G.; Pectasides, D.; Dimopoulos, M.A.; Papadimitriou, C. Endothelial vascular toxicity from chemotherapeutic agents: Preclinical evidence and clinical implications. Cancer Treat. Rev. 2012, 38, 473-483. [CrossRef] [PubMed]

27. He, H.; Luo, Y.; Qiao, Y.; Zhang, Z.; Yin, D.; Yao, J.; You, J.; He, M. Curcumin attenuates doxorubicin-induced cardiotoxicity via suppressing oxidative stress and preventing mitochondrial dysfunction mediated by 14-3 g. Food Funct. 2018 , 9, 4404-4418. [CrossRef]

28. Henidi, H.A.; Al-Abassi, F.A.; El-Mosselhi, M.A.; El-Bassossy, H.M.; Al-Abd, A.M. Despite blocking doxorubicin-induced vascular damage, quercetin ameliorated antibreast cancer activity. Oxid. Med. Cell Longev. 2020, 8157640.

29. Kyaw, M.; Yoshizumi, M.; Tsuchiya, K.; Kirima, K.; Tamaki, T. Antioxidants inhibit JNK and p38 MAPK activation but not ERK $1 / 2$ activation by angiotensin II in rat aortic smooth muscle cells. Hypertens. Res. 2001, 24, 251-261. [CrossRef] 
30. Comisia de Coordonare a Farmacopeei Române. Farmacopeea Română, Ediția X; Editura Medicala: Bucharest, Romania, 2018.

31. Council of Europe. Pharmacopée Européenne EDQM; Council of Europe: Strasbourg, France, 2019.

32. Singleton, V.; Orthofer, R.; Lamuela-Raventós, R.M. Analysis of total phenols and other oxidation substrates and antioxidants by means of Folin-Ciocâlteu reagent. Oxid. Antioxid. 1999, 299, 152-178.

33. Blainski, A.; Lopes, G.C.; De Mello, J.C.P. Application and analysis of the folin ciocalteu method for the determination of the total phenolic content from Limonium brasiliense L. Molecules 2013, 18, 6852-6865. [CrossRef]

34. Marinova, D.; Ribarova, F.; Atanassova, M. Total phenolic and total flavonoids in Bulgarian fruits and vegetables. J. Univ. Chem. Technol. Metall. 2005, 40, 255-260.

35. Chang, C.; Yang, M.; Wen, H.M.; Chern, J.C. Estimation of total flavonoid content in propolis by two complementary colometric methods. J. Food Drug Anal. 2002, 10, 178-182. [CrossRef]

36. Pourmorad, F.; Hosseinimehr, S.J.; Shahabimajd, N. Antioxidant activity, phenol and flavonoid contents of some selected Iranian medicinal plants. Afr. J. Biotechnol. 2006, 1, 1142-1145.

37. Miliauskas, G.; Venskutonis, P.R.; van Beek, T.A. Screening of radical scavenging activity of some medicinal and aromatic plant extracts. Food Chem. 2004, 85, 231-237. [CrossRef]

38. Jurca, T.; Baldea, I.; Filip, G.A.; Olteanu, D.; Clichici, S.; Pallag, A.; Vicas, L.; Marian, E.; Micle, O.; Crivii, C.B.; et al. Phytocomplex consisting of Tropaeolum majus L. and Salviae officinalis L. extracts alleviates the inflammatory response of dermal fibroblasts to bacterial lipopolysaccharides. Oxid. Med. Cell. Longev. 2020, 2020, 8516153. [CrossRef] [PubMed]

39. Pavaloiu, R.D.; FawziaSha, A.T.; Bubueanu, C.; Neagu, G.; Albulescu, A.; Hlevca, C.; Nechifor, G. Release of polyphenols from liposomesloaded with Echinacea purpurea. Rev. Chim. 2018, 9, 2315-2317. [CrossRef]

40. Nguyen, T.L.; Nguyen, T.H.; Nguyen, D.H. Development and in vitro evaluation of liposomes using soy lecithin to encapsulate paclitaxel. Int. J. Biomater. 2017, 2017, 8234712. [CrossRef]

41. Olariu, I.; Coneac, G.; Hîrjău, M.; Popoiu, C.; Muț, A.M.; Vlaia, V.; Sevastre, A.S.; Lupuliasa, D.; Vlasie, L. Evaluation of the barrierpotential of somesynthetic membranes in testing the in vitro tenoxicam release from hydrogels, using the experimental model with Franz diffusion cells. Farmacia 2019, 67, 73-80. [CrossRef]

42. Pallag, A.; Filip, G.A.; Olteanu, D.; Clichici, S.; Baldea, I.; Jurca, T.; Micle, O.; Vicaș, L.; Marian, E.; Sorițău, O.; et al. Equisetum arvense $\mathrm{L}$. extract induces antibacterial activity and modulates the oxidative stress, inflammation and apoptosis in endothelial vascular cells exposed to hyperosmotic stress. Oxid. Med. Cell. Longev. 2018, 3060525. [CrossRef]

43. Domsa, E.M.; Filip, G.A.; Olteanu, D.; Baldea, I.; Clichici, S.; Muresan, A.; David, L.; Moldovan, B.; Para, I.; Suciu, M.; et al. Gold nanoparticles phytoreduced with Cornus mas extract mitigate some of gliadin effects on Caco-2 cells. Physiol. Pharmacol. 2020, 71, 201-212.

44. Conti, M.; Moran, P.C.; Levillain, P. Improved fluorimetric determination of malondialdehyde. Clin. Chem. 1991, 37, 1273-1275. [CrossRef]

45. Baldea, I.; Florea, A.; Olteanu, D.; Clichici, S.; David, L.; Moldovan, B.; Cenariu, M.; Achim, M.; Suharoschi, R.; Danescu, S.; et al. Effects of silver and gold nanoparticles phytosynthesized with Cornus mas extract on oral dysplastic human cells. Nanomedicine 2020, 15, 55-75. [CrossRef]

46. Seo, S.H.; Lee, S.H.; Cha, P.H.; Kim, M.Y.; Min, D.S.; Choi, C.Y. Polygonum aviculare L. and its active compounds, quercitin hydrate, caffeic acid, and rutin, activate the Wnt/ $\beta$-catenin pathway and induce cutaneous wound healing. Phytother. Res. 2016, 30, 848-854. [CrossRef]

47. Nugroho, A.; Kim, E.J.; Choi, J.S.; Park, H.J. Simultaneous quantification and peroxynitrite-scavenging activities of flavonoids in Polygonum aviculare L. herb. J. Pharma. Biomed. Anal. 2014, 89, 93-98. [CrossRef]

48. Cai, Y.; Wu, L.; Lin, X.; Hu, X.; Wang, L. Phenolic profiles and screening of potential $\alpha$-glucosidase inhibitors from Polygonum aviculare L. leaves using ultra-filtration combined with HPLC-ESI-qTOF-MS/MS and molecular docking analysis. Ind. Crops. Prod. 2020, 15, 112673. [CrossRef]

49. Yunuskhodzhaeva, N.A.; Eshbakova, K.A.; Abdullabekova, V.N. Flavonoid composition of the herb Polygonum aviculare. Chem. Nat. Comp. 2010, 46, 803-804. [CrossRef]

50. Dejeu, L.; Vicaș, L.; Jurca, T.; Pallag, A.; Costea, T.; Marian, E. Preparation and characterization of liposomes loaded with polyphenols extracted from Callendulae flos. Anim. Husb. Food Sci. Technol. 2019, 18, 129-134.

51. Glavas-Dodov, M.; Goracinova, K.; Mladenovska, K.; Fredro-Kumbaradzi, E. Release profile of docaine $\mathrm{HCl}$ from topical liposomal gel formulation. Int. J. Pharm. 2002, 242, 1-4. [CrossRef]

52. Akbarzadeh, A.; Rezaei Sadabady, R.; Davaran, S.; Woo-Joo, S.; Zarghami, N.; Hanifehpour, Y.; Samiei, M.; Kouhi, M.; NejatiKoshki, N. Liposome: Classification, preparation, and applications. Nanoscale Res. Lett. 2013, 8, 102. [CrossRef] [PubMed]

53. Vorselen, D.; Piontek, M.C.; Roos, H.; Wuite, G.J.L. Mechanical characterization of liposomes and extracellular vesicles, a protocol. Front Mol. Biosci. 2020, 7, 139. [CrossRef]

54. Schnitzer, C.; Ripperger, S. Influence of surface roughness on streaming potential method. Chem. Eng. Technol. 2008, 31, 1696-1700. [CrossRef]

55. Valsesia, A.; Desmet, C.; Ojea-Jiménez, I.; Oddo, A.; Capomaccio, R.; Rossi, F.; Colpo, P. Direct quantification of nanoparticle surface hydrophobicity. Comun. Chem. 2018, 1, 53. [CrossRef]

56. Leonid, A.K.; Tepper, F.; Vesga, Y.; Tatiana, G.K. Boehmite and akaganeite 1d and 2d mesostructures: Synthesis, growth mechanism, ageing characteristics and surface nanoscale roughness effect on water purification. Hindawi J. Nanomat. 2019, 9516156, 1-10. 
57. Gilliam, A.A.; Clair, D.K. Chemotherapy-induced weakness and fatigue in skeletal muscle: The role of oxidative stress. Antioxid. Redox Signal. 2011, 15, 2543-2563. [CrossRef] [PubMed]

58. Scheede-Bergdahl, C.; Jagoe, R.T. After the chemotherapy: Potential mechanisms for chemotherapy-induced delayed skeletal muscle dysfunction in survivors of acute lymphoblastic leukaemia in childhood. Front Pharmacol. 2013, 4, 49. [CrossRef]

59. Xiong, Y.; Liu, X.; Lee, C.P.; Ho, B.H.L.Y.S. Attenuation of doxorubicin-induced contractile and mitochondrial dysfunction in mouse heart by cellular glutathione peroxidase. Free. Rad. Biol. Med. 2006, 41, 46-55. [CrossRef] [PubMed]

60. Cappetta, D.; Rossi, F.; Piegari, E.; Quaini, F.; Berrino, L.; Urbanek, K.; Angelis, A. Doxorubicin targets multiple players: A new view of an old problem. Pharmacol. Res. 2018, 127, 4-14. [CrossRef]

61. Gilliam, L.A.A.; Ferreira, L.F.; Bruton, J.D.; Moylan, J.S.; Westerblad, H.; Clair, D.K.; Reid, M.B. Doxorubicin acts through tumor necrosis factor receptor subtype 1 to cause dysfunction of murine skeletal muscle. J. Appl. Physiol. 2009, 107, 1935-1942. [CrossRef] [PubMed]

62. Minotti, G.; Cairo, G.; Monti, E. Role of iron in anthracycline cardiotoxicity: New tunes for an old song? FASEB J. 1999, 13, 199-212. [CrossRef]

63. Dudka, J.; Burdan, F.; Korga, A.; Iwan, M.; Madei-Czerwonka, B.; Cendrowska-Pinkosz, M.; Korobowicz-Markiewicz, A.; Jodlowska-Jedrvch, B.; Matysiak, W. Intensification of doxorubicin-related oxidative stress in the heart by hypothyroidism is not related to the expression of cytochrome P450 NADPH-reductase and inducible nitric oxide synthase, as well as activity of xanthine oxidase. Oxid. Med. Cell. Longev. 2012, 139327. [CrossRef]

64. Mirzaei, S.; Zarrabi, A.; Hashemi, F.; Zabolian, A.; Saleki, H.; Azami, N.; Hamzehlou, S.; Farahani, M.V.; Hushmandi, K.; Ashrafizadeh, M.; et al. Nrf2 signaling pathway in chemoprotection and doxorubicin resistance: Potential application in drug discovery. Antioxidants 2021, 10, 349. [CrossRef]

65. Lorenzo, E.; Ruiz-Ruiz, C.; Quesada, A.J.; Hernandez, G.; Rodriguez, A.; Lopez-Rivas, A.; Redondo, J.M. Doxorubicin induces apoptosis and CD95 gene expression in human primary endothelial cells through a p53-dependent mechanism. J. Biol. Chem. 2002, 277, 10883-10892. [CrossRef] [PubMed]

66. Wu, Q.; Liu, X.X.; Lu, D.Y.; Li, Y.T.; Sun, J.; Lan, Y.Y.; Liu, T. Protective effect of polygonum orientale flower extract on $\mathrm{H}_{2} \mathrm{O}_{2}$-induced oxidative damage of HUVEC cells. J. Chin. Mater. Med. 2018, 43, 1008-1013.

67. Lv, L.S.; Gu, X.H.; Tang, J.; Ho, C.T. Antioxidant activity of stilbene glycoside from Polygonum multiflorum Thunb in vivo. Food Chem. 2007, 104, 1678-1681. [CrossRef]

68. Jovanović, M.; Srdić-Rajić, T.; Svirčev, E.; Jasnić, N.; Nikolić, B.; Bojić, S.; Stević, T.; Knežević-Vukčević, J.; Mitić-Ćulafić, D. Evaluation of anticancer and antimicrobial activities of the Polygonum maritimum ethanol extract. Arch. Biol. Sci. 2018, 70, 665-673. [CrossRef]

69. Bralley, E.E.; Greenspan, P.; Hargrove, J.L.; Wicker, L.; Hartle, D.K. Topical anti-inflammatory activity of Polygonum cuspidatum extract in the TPA model of mouse ear inflammation. J. Inflamm. 2008, 5, 1. [CrossRef]

70. Incalza, M.A.; D'Oria, R.; Natalicchio, A.; Perrini, S.; Laviola, L.; Giorgino, F. Oxidative stress and reactive oxygen species in endothelial dysfunction associated with cardiovascular and metabolic diseases. Vasc. Pharmacol. 2018, 100, 1-19. [CrossRef]

71. Xu, A.; Deng, F.; Chen, Y.; Kong, Y.; Pan, L.; Liao, Q.; Rao, L.; Xie, L.; Yao, C.; Li, S.; et al. NF-kB pathway activation during endothelial-to-mesenchymal transition in a rat model of doxorubicin-induced cardiotoxicity. Biomed. Pharmacother. 2020, 130, 110525. [CrossRef] [PubMed]

72. Nozaki, N.; Shishido, T.; Takeishi, S.; Kubota, L. Modulation of doxorubicin-induced cardiac dysfunction in toll-like receptor-2knockout mice. Circulation 2004, 110, 2869-2874. [CrossRef]

73. El-Agamy, D.S.; El-Harbi, K.M.; Khoshhal, S.; Ahmed, N.; Elkablawy, M.A.; Shaaban, A.A.; Abo-Haded, H.M. Pristimerin protects against doxorubicin-induced cardiotoxicity and fibrosis through modulation of Nrf2 and MAPK/NF-kB signaling pathways. Cancer Manag. Res. 2019, 11, 47-61. [CrossRef]

74. Gaspar-Pereira, S.; Fullard, N.; Townsend, P.A.; Banks, P.S.; Ellis, E.L.; Fox, C.; Maxwell, A.G.; Murphy, L.B.; Kirk, A.; Bauer, R.; et al. The NF-kappaB subunit c-Rel stimulates cardiac hypertrophy and fibrosis. Am. J. Pathol. 2012, 180, 929-939. [CrossRef]

75. Aoki, M.; Nata, T.; Morishita, R.; Matsushita, H.; Nakagami, H.; Yamamoto, K.; Yamazaki, K.; Nakabayashi, M.; Ogihara, T.; Kaneda, Y. Endothelial apoptosis induced by oxidative stress through activation of NF-jB: Antiapoptotic effect of antioxidant agents on endothelial cells. Hypertension 2001, 38, 48-55. [CrossRef]

76. Arlt, A.; Vorndamm, J.; Breitenbroich, M.; Folsch, U.R.; Kalthoff, H.; Schmidt, W.E.; Schafer, H. Inhibition of NF-jB sensitizes human pancreatic carcinoma cells to apoptosis induced by etoposide (VP16) or doxorubicin. Oncogene 2001, 20, 859-868. [CrossRef]

77. Luo, J.L.; Kamata, H.; Karin, M. The anti-death machinery in IKK/NF-kappaB signaling. J. Clin. Immunol. 2005, 25, 541-550. [CrossRef]

78. Perkins, N.D.; Gilmore, T.D. Good cop, bad cop: The different faces of NF-kB. Cell Death Differ. 2006, 13, 759-772. [CrossRef]

79. Liu, Z.G.; Hsu, H.; Goeddel, D.V.; Karin, M. Dissection of TNF receptor 1 effector functions: JNK activation is not linked to apoptosis while NF-kappaB activation prevents cell death. Cell 1996, 87, 565-576. [CrossRef]

80. Van Antwerp, D.J.; Martin, S.J.; Kafri, T.; Green, D.R.; Verma, I.M. Suppression of TNF-alpha-induced apoptosis by NF-kappaB. Science 1996, 274, 787-789. [CrossRef] [PubMed]

81. Heermeier, K.; Leicht, W.; Palmetshofer, A.; Ullrich, M.; Wanner, C.; Galle, J. Oxidized LDL suppresses NF-jB and overcomes protection from apoptosis in activated endothelial cells. J. Am. Soc. Nephrol. 2001, 12, 456-463. [CrossRef] [PubMed] 
82. Kasai, S.; Shimizu, S.; Tatara, Y.; Mimura, J.; Itoh, M. Regulation of Nrf2 by mitochondrial reactive oxygen species in physiology and pathology. Biomolecules 2002, 10, 320. [CrossRef] [PubMed]

83. Aladaileh, S.H.; Abukhalil, M.H.; Saghir, S.A.M.; Hanieh, H.; Alfwuaires, M.A.; Almaiman, A.A.; Bin-Jumah, M.; Mahmoud A.M. Galangin activates Nrf2 signaling and attenuates oxidative damage, inflammation, and apoptosis in a rat model of cyclophosphamide-induced hepatotoxicity. Biomolecules 2019, 9, 346. [CrossRef]

84. Jiang, G.; Liang, X.; Huang, Y.; Lan, Z.; Zhang, Z.; Su, Z.; Fang, Z.; Lai, Y.; Yao, W.; Liu, T. p62 promotes proliferation, apoptosis-resistance and invasion of prostate cancer cells through the Keap1/Nrf2/ARE axis. Oncol. Rep. 2020, 43, 1547-1557. [CrossRef]

85. Li, C.; Wang, T.; Zhang, C.; Xuan, J.; Su, C.; Wang, Y. Quercetin attenuates cardiomyocyte apoptosis via inhibition of JNK and p38 mitogen-activated protein kinase signaling pathways. Genes 2016, 577, 275-280. [CrossRef]

86. Lozano, O.; Lázaro-Alfaro, A.; Silva-Platas, C.; Oropeza-Almazán, Y.; Torres-Quintanilla, A.; Bernal-Ramírez, T.; Alves-Figueiredo, H.; García-Rivas, G. Nanoencapsulated quercetin improves cardioprotection during hypoxia-reoxygenation injury through preservation of mitochondrial function. Oxid. Med. Cell. Longev. 2019, 7683051. [CrossRef]

87. Qureshi, W.A.; Zhao, R.; Wang, H.; Ji, T.; Ding, Y.; Ihsan, A.; Mujee, A.; Nie, G.; Zhao, Y. Co-delivery of doxorubicin and quercetin via mPEG-PLGA copolymer assembly for synergistic anti-tumor efficacy and reducing cardio-toxicity. Sci. Bull. 2016, 61, 1689-1698. [CrossRef]

88. Sharma, A.; Parikh, M.; Shah, H.; Gandhi, T. Modulation of Nrf2 by quercetin in doxorubicin-treated rats. Heliyon 2020, 6, e03803 [CrossRef]

89. Mikstacka, R.; Rimando, A.; Ignatowicz, E. Antioxidant effect of trans-resveratrol, pterostilbene, quercetin and their combinations in human erythrocytes in vitro. Plant Foods Hum. Nutr. 2010, 65, 57-63. [CrossRef] [PubMed]

90. Khadka, P.; Ro, J.; Kim, H.; Kim, L.; Kim, J.T.; Kim, H.; Cho, J.M.; Yun, G.; Lee, L. Pharmaceutical particle technologies: An approach to improve drug solubility, dissolution and bioavailability. Asian J. Pharm. Sci. 2014, 9, 304-316. [CrossRef]

91. Stone, W.L.; Smith, M. Therapeutic uses of antioxidant liposomes. Mol. Biotechnol. 2004, 27, 217-230. [CrossRef] [PubMed] 